\title{
Education, Gender, Religion, Politics: What Priorities for Cultural Integration Policies in Switzerland?
}

\author{
Pierre KOHLER \\ Graduate Institute of International and Development Studies
}

\begin{abstract}
This paper explores cultural integration paths of eight migrant groups in Switzerland. It specifically analyzes the evolution of objective behaviors and subjective attitudes of migrants from the first to the second generation. In order to deepen the analysis, the cultural integration of migrants is further examined from different perspectives: across cohorts (older vs. younger migrants) and across types of couples (individuals in endogamous vs. mixed couples). Gender differences are also paid attention to. First, behaviors are examined by looking at performances of migrants at school (educational attainment and gender gap). As women play a key role in the transmission of cultural traits and the socialization of the second generation, the focus then turns to their position in the couple (marriage, intermarriage, age and education gap between partners, early marriage, cohabitation, fertility, divorce) and in the labor market (labor force participation). Finally, this paper proposes to look at migrants' use of language, their feelings towards Switzerland, as well as their attitudes towards gender, religious and political issues. Evidence points to overall convergence. As the most striking and lasting differences across groups do not pertain to educational achievement, religious or political attitudes but to gender-related attitudes and, even more, to gender-related behaviors in endogamous couples, it appears that migration-related gender issues and migration-specific "household dynamics" should be taken into account in the design of future cultural integration policies.
\end{abstract}

(C) The Authors.

All rights reserved. No part of this paper may be reproduced without the permission of the authors. 


\title{
Education, Gender, Religion, Politics: What Priorities for Cultural Integration Policies in Switzerland?
}

\author{
Pierre Kohler*
}

April 21, 2012

\begin{abstract}
This paper explores cultural integration paths of eight migrant groups in Switzerland. It specifically analyzes the evolution of objective behaviors and subjective attitudes of migrants from the first to the second generation. In order to deepen the analysis, the cultural integration of migrants is further examined from different perspectives: across cohorts (older vs. younger migrants) and across types of couples (individuals in endogamous vs. mixed couples). Gender differences are also paid attention to. First, behaviors are examined by looking at performances of migrants at school (educational attainment and gender gap). As women play a key role in the transmission of cultural traits and the socialization of the second generation, the focus then turns to their position in the couple (marriage, intermarriage, age and education gap between partners, early marriage, cohabitation, fertility, divorce) and in the labor market (labor force participation). Finally, this paper proposes to look at migrants' use of language, their feelings towards Switzerland, as well as their attitudes towards gender, religious and political issues. Evidence points to overall convergence. As the most striking and lasting differences across groups do not pertain to educational achievement, religious or political attitudes but to gender-related attitudes and, even more, to gender-related behaviors in endogamous couples, it appears that migration-related gender issues and migration-specific "household dynamics" should be taken into account in the design of future cultural integration policies.
\end{abstract}

JEL Classification: F22, Z10, Z13

Keywords: immigration, migration, culture, integration, Switzerland

${ }^{*}$ Department of Economics, Graduate Institute of International and Development Studies, University of Geneva. E-mail: pierre.kohler@graduateinstitute.ch 


\section{Introduction $^{1}$}

Until the beginning of the industrial revolution, Switzerland was mainly an emigration country. Since the end of the nineteenth century, Switzerland and inflowing migrants have maintained a mutually beneficial relationship interspersed with difficult episodes. ${ }^{2}$ Despite the impossibility of an accepted definition of (the Swiss) national identity, populist right wing political parties recurrently attempt to instrumentalize successive migration waves to strengthen the fear that Switzerland may lose its identity to migrants unable to integrate culturally into society. The recent successes of popular anti-migrant initiatives stress the many open questions that remain concerning the handling of cultural integration issues in Switzerland (D'Amato, 2008).

Cultural integration can be defined as the evolution of behaviours, attitudes, daily life habits, beliefs, etc. (Wanner et al., 2002). Different schools of thought exist in cultural integration literature. Assimilation theory assumes cultural differences progressively level out whereas multiculturalism insists on their persistence over time (Alba and Nee, 1997). Proponents of de-constructivism and system theories have criticized "groupist" approaches arguing that groups are a product of social processes or discourse and do not exist a priori. However, empirical observation tends to hint that none of these theories are adequate and that the relation between ethnicity, identity, behaviours and attitudes is a complex multi-level evolutionary phenomenon (Wimmer 2008). As an example, a study conducted in three migrant neighborhoods in Swiss cities shows that even if migrants do not primarily define themselves in ethnic terms, the majority of their social interactions occur within the group they belong to (Wimmer, 2004). Cultural integration may affect behaviours and attitudes in different ways. Furthermore, the cultural dimension of the integration process of migrants is influenced by economic factors as well as the social and political context in which the integration process is occurring. Wage and employment discrimination, legal incentives determining access to citizenship and host society culture are some of the factors influencing the cultural integration of migrants (Kohler, 2012). Such evidence calls for further research on the stability of group boundaries and their transformation, so as to better understand the evolutionary nature of group formation and how groups insert themselves in the host society. Qualitative studies have generated knowledge over the cultural integration patterns of specific communities residing in Switzerland. However, only few quantitative studies have been conducted on that

\footnotetext{
${ }^{1}$ An earlier version of this paper was posted online previously. This revised version is also part of a thesis (Kohler, 2012) on the economic and cultural integration of migrants in Switzerland, reverse causation between these two dimensions of the integration process, and the role of host society culture. Whereas each dimension is usually examined separately, this study proposes a systemic approach to investigate both the economic and cultural dimensions of migrant integration, their interaction as well as the influence of the broader social context. For a more detailed and critical contextualisation of this paper, see http://mpra.ub.uni-muenchen.de/38129/1/MPRA_paper_38129.pdf

${ }^{2}$ See next section for a brief review of migration history and policy in Switzerland.
} 
subject.

This paper contributes to this debate by specifically exploring the cultural integration paths of eight migrant groups from the first to the second generation. It traces the evolution of selected behaviours and attitudes, which are taken as indicative of cultural integration. Different perspectives are proposed to deepen the analysis. First, differences across cohorts are used to investigate change and continuity over time (Georgiadis and Manning, 2011) and see if younger migrants depart from behaviours and attitudes of older migrants. ${ }^{3}$ Second, to explore the role of intermarriage as a factor (and not only an outcome) of integration (Waldis, 2008), differences across individuals in endogamous and mixed couples are examined. Can significant patterns be identified? And what is the effect of education? These are some of the questions explored in this paper. Special attention is given to migrant women, as they play a key role in the transmission of cultural traits and in the socialization process of the second generation on whom most policy efforts are targeted.

The remainder of this introduction proposes a short overview of migration history and policy in Switzerland since the mid-nineteenth century. Section 2 provides a review of related quantitative studies and section 3 presents a snapshot of the migrant population in Switzerland as well as pertinent data. Section 4 defines the indicators of cultural integration as well as the empirical model used to investigate the cultural integration of migrants. Section 5 presents the results of the investigation of the evolution of migrants' behaviours by examining their performances at school (educational achievement and gender education gap) as well as their position in the couple (marriage, intermarriage, age and education gap between partners, early marriage, cohabitation, fertility, divorce) and in the labour market (labor force participation). This section also covers their subjective attitudes by examining their use of national languages, their feelings towards Switzerland as well as their gender, religious and political attitudes. The last section concludes by summarizing key findings and proposes recommendations for future integration policies.

\subsection{Immigration history and policy: "Ueberfremdung" and its shadow}

For centuries, Switzerland was a country of emigration before becoming an immigration country. In 1850, migrants were almost non-existent in Switzerland, except for the Huguenots (Henry et al., 1995). The construction of infrastructure necessary for the unfolding industrial revolution created an excess demand for manpower. At that time, foreigners were welcome and perceived as indispensable. The Swiss government signed recruitment agreements with neighboring countries, granting migrants the same rights as nationals. Two years of residence were sufficient to acquire Swiss citizenship. This policy was in line with the belief

\footnotetext{
${ }^{3}$ In this paper, migrants born before 1970 are labelled as "old" and those born after 1970 as "young."
} 


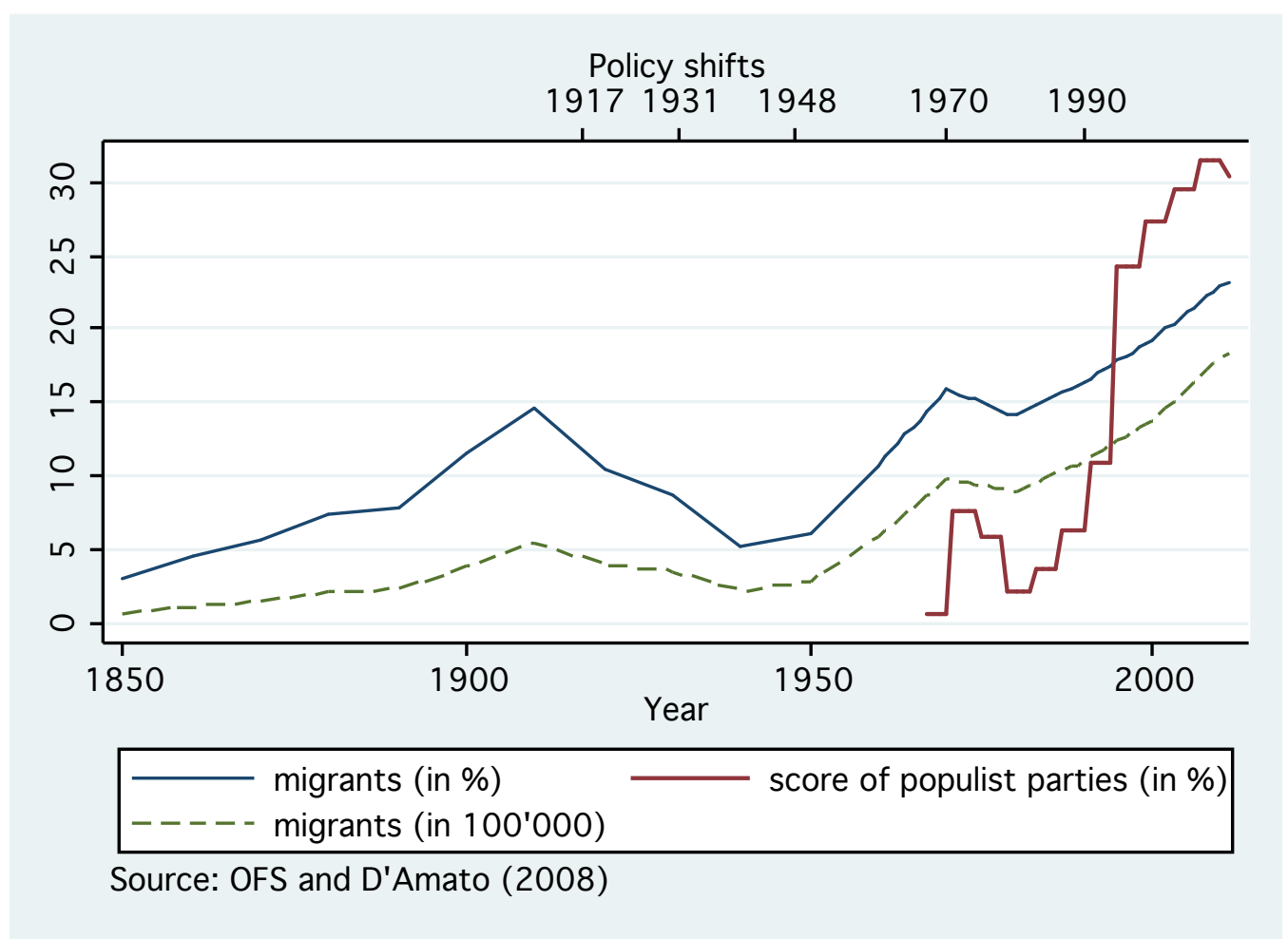

Figure 1: Migrant population and right wing populist parties in Switzerland (1850-2011)

that naturalization was the most sui way to assimilate migrants (Wicker, 2003). Figure 1 shows that the share of foreigners living in Switzerland progressively rose and reached 15\% in 1910, one of the highest rates in Europe.

The outbreak of the First World War signaled the beginning of a lasting change in the perception of migrants as a threat to Swiss culture. Conservative circles brought into the political debate the idea of "Ueberfremdung," the fear that Swiss identity will be dissolved with the inflow of too many foreigners. In 1917, the Central Office for Aliens Police was created in order to better monitor migrant population. In 1931, the Federal Law on the Settlement and Residence of Foreigners engraved in law the transmutation of "migrants" into "foreigners" (Wicker, 2003). It also made residence and naturalization more difficult. In the 1930s, a more malleable version of the "Ueberfremdung" idea, the "Geistige Landesverteidigung", literally the spiritual national defense, insisted on the duty of individuals to defend typical Swiss values. With Nazi and fascist regimes at the border, liberal circles progressively rallied conservatives around the flag to promote "Swiss" values such as cultural diversity, democracy or technological progress. This episode of Swiss history is important because the national "culture of threat" that developed in Switzerland and the representation of foreigners as a danger to Swiss identity had a lasting impact on Swiss collective identity and immigration 
policy (Riano and Wastl-Walter, 2006). During that period, the proportion of migrant population dropped sharply and reached $5 \%$ at the eve of World War II.

In the second half of the 20th century, three successive waves of immigration brought different types of migrants to Switzerland. The defensive attitude inherited from the previous period still weighted on policy decisions. While the government attempted to provide cheap labour to the economy, it always had to pay attention to underlying xenophobic feelings prompt to burst onto the political scene. Like other countries, Switzerland opted for a "Gastarbeiter" system. The first recruitment agreement was signed with Italy in 1948 and was followed by an inflow of Italian manpower. Spaniards came soon after. Despite a quota system, immigration kept rising. In 1970, the Schwarzenbach initiative, which proposed to expel one third of migrants and impose harsher quotas, was rejected only by $54 \%$ in one of the highest poll turnouts in Swiss history. The federal government reacted by imposing more restrictive quotas, but it was mostly the non-renewal of permits that drove out migrants. This was also a convenient way for Switzerland to export its unemployment. During the economic crisis of the 1970 s, $67 \%$ of the 340 '000 workers who lost their jobs were migrants (Mahnig and Piguet, 2003). As the economy recovered in the 1980s, the second wave of migration followed a different pattern. Portuguese, Yugoslav and Turkish workers, as well as refugees from Sri-Lanka, Vietnam and the Middle East also brought their families with them. After a decline in the 1970s, migrant population again exceeded $15 \%$ in 1990. Pressure from European countries for the improvement of conditions for their nationals drove Swiss authorities to reconsider their immigration policy. The idea to create a point system or to implement a "three circles" policy based on the concept of "cultural distance" of migrants were debated as a means to satisfy Switzerland's neighbors without alienating xenophobic voters. In the 1990s, Switzerland started to apply a "three circles" policy, defining an inner circle and outer circles, and creating a hierarchy favoring individuals from EU/EFTA countries over those from the US and the rest of the world. Through bilateral agreements, EU/EFTA citizens are granted the same living and working rights as the Swiss (Mahnig and Piguet, 2003), while, for other countries, immigration is restricted to highly-qualified individuals only. Beyond the pragmatism of Swiss authorities, this political move also hints at the shift of symbolic barriers and a change in how Swiss define foreigners and themselves (Wicker, 2003). However, this new policy could not prevent unwanted migrants to come to Switzerland. During this period, the third wave of migrants was mostly composed of refugees from former Yugoslavia, but also from Africa, as well as highly qualified workers, mainly from neighboring countries (Piguet, 2009).

Despite different restrictive policies, migrant population has kept rising and the proportion of foreigners officially reached $22.9 \%$ in 2009 (OFS). As it became obvious that many migrants will never return to their 
home countries, politicians could no longer escape the question of migrant integration. Some cantons had started to use their autonomy in matters of education, religious matters, the attribution of local civic rights to deal with integration-related issues, but their practices are heterogeneous and resources very limited (Cataccin and Bühlent, 2005). The legal basis for a coherent federal policy was only set up in 1998 when the integration of migrants became an item on the Swiss political agenda and the Federal Law on the Settlement and Residence of Foreigners was once more amended to allow the government to subsidize the integration of "foreigners". In 2001, a budget of around 10 million Swiss francs was accepted and has barely increased since (OFM, 2006). The previous year, an order of the government defined the objectives of integration and the tasks of the Federal Commission for Foreigners. The Central Office for Aliens Police was changed into the Federal Migration Office (Wicker, 2003). For a majority of the Swiss population, Western and Southern European migrants may be considered as economic competitors, but not as a threat to the Swiss identity. This empathy, however, does not extend to "non-European" migrants. In 2005, a new Federal Law on Foreigners passed defining in depth the objectives and principles of integration policy as well as the competence of the government (OFM, 2006). The fact that a conservative government has initiated such changes during a period where the populist right wing has risen to become the strongest political force in the federal parliament indicates the design of an integration strategy is politically costly, but indispensable (D'Amato, 2008). As in other countries, many voters are caught between the fear that the country they know may change and the necessity to adapt to a globalizing economy and society.

\section{Related literature}

The findings of the few existing quantitative studies relevant for this investigation are briefly presented below, with some of the results referred to later, as necessary. ${ }^{4}$ Qualitative studies are not presented here, but the results of some of them will be mentioned when interpreting the results.

Bauer and Riphahn (2005) investigated the performance of migrants at school through the study of intergenerational patterns of educational attainment. Fibbi et al. (2005) looked at statistical differences across gender and between naturalized and non-naturalized second-generation migrants. They also proposed an analysis of the probability to have a weak education level, to be in the labour force, to be unemployed and to acquire Swiss citizenship by regressing independent variables on a set of origin dummies (Germany,

\footnotetext{
${ }^{4}$ International economic literature on cultural integration has rapidly grown in recent years and it is not possible to review it entirely. In Switzerland, sociologists and demographers were the first to conduct cultural integration studies based on larger datasets as they became available. By contrast, economists mainly focused on the economic integration of migrants in the labour market.
} 
France, Italy, Spain, Portugal, Turkey, and six former Yugoslavian provinces) and other controls. Wanner et al. (2003, 2005b) prepared a comprehensive study on female labour force participation. Other reports proposed statistics only on socio-professional and household characteristics of migrants (Wanner, 2004), on migrants, the use of language and religion (OFS, 2005) or on migrant families, highlighting their specificity and their role in the migration and integration process (Fibbi et al. 2005b).

Quantitative studies on subjective attitudes of migrants are even less numerous and, as surveys containing such data are costly to conduct, they usually rely on small samples. Wanner et al. (2002) investigate determinants of the values and beliefs of migrants based on data from the first two waves (1999 and 2000) of the Swiss Household Panel (SHP). They regressed many indicators on origin dummies (Swiss, Italian, Spanish/Portuguese, other European Economic Community/European Free Trade Association, other Europe, rest of the world) and controlled whether respondents have one or two parents of foreign origin.

This study is the first to systematically examine the evolution of the behaviours and attitudes of migrants to better understand their cultural integration paths from the first to the second generation. Previous articles either only focused on the second-generation or attributed a common factor to the second-generation when considering all migrants. It also differs from existing literature in the way migrant groups are defined. Although European migrants form the bulk of migrant population in Switzerland, the focus is not on European national communities, but on a limited number of broadly defined migrant categories that are geographically more balanced.

\section{Data}

\subsection{Migrant groups definition and composition}

Table 1 shows that, when the last census was conducted in Switzerland in 2000, 29\% of the population was of foreign descent and more than $20 \%$ foreigners. First-generation migrants are born abroad, whereas secondgeneration migrants are born in Switzerland, but are of foreign origin. ${ }^{5}$ The proportion of second-generation compared to first-generation migrants is a rough indicator of the length of stay of a group in Switzerland.

Groups of migrants presented in table 1 are based on an aggregated United Nations typology and correspond to broad regions of origin. Besides natives, eight groups of migrants are formed: Western Europe and Anglo-Saxon countries (WE), Southern Europe (SE), Eastern Europe (EE), Africa (AF), Turkey, the Middle East and Maghreb (TMM), Latin Amercia (LA), Asia (AS) and South and Central Asia (SCA). ${ }^{6}$ Any such

\footnotetext{
${ }^{5}$ More details on categorization issues can be found in Section 2.

${ }^{6}$ The categories include the following countries: (1) WE: Australia, Austria, Belgium, Canada, Denmark, Finland, France,
} 
Table 1: Migrants living in Switzerland in 2000 by region of origin and generation

\begin{tabular}{lrrr} 
Region of origin & All & 1st generation & 2nd generation \\
\hline \hline Natives (\%) & 70.78 & & \\
Immigrants (\%) & 29.22 & 20.07 & 9.14 \\
\hline Of which (\%) & & & \\
WE & 27.34 & 28.12 & 25.65 \\
SE & 34.79 & 28.62 & 48.35 \\
EE & 21.05 & 24.06 & 14.44 \\
AF & 2.03 & 2.51 & 0.98 \\
TMM & 6.84 & 6.99 & 6.49 \\
SA & 2.82 & 3.44 & 1.47 \\
AS & 2.52 & 3.29 & 0.8 \\
SCA & 2.61 & 2.98 & 1.82 \\
\hline \hline Source: Swiss census, 2000 & &
\end{tabular}

Source: Swiss census, 2000

groupings can be the subject of a debate. Is it still relevant to distinguish between Southern, Western and Central Europe? Should Turkey be considered part of Eastern Europe as Russia is? There is no clear-cut solution to such issues, but the composition of the different groups will be given careful attention in the analyses made throughout this paper.

The three first groups are significantly larger than the five remaining ones and represent $83 \%$ of migrant population. The first group gathers Western and Northern Europeans as well as Anglo-Saxons. Three quarters of them are from neighboring Germany (37\%), France (26\%) and Austria (12\%) and are not part of any specific wave of migration. Italians dominate the Southern European group (65\%); Spaniards (19\%) and Portuguese (14\%) are also sizeable communities. The group of Eastern Europeans is largely dominated by former Yugoslavia (85\%), but remains heterogeneous. Migrants from this country first came as economic migrants in the 1980s, and then massively as refugees fleeing the civil war after 1991. The largest community comes from former Serbia-Montenegro (48\%), but half of them are Muslims from Kosovo. Bosnia and Herzegovina (13\%), Macedonia (12\%) and Croatia (9\%) follow in terms of size.

Immigration from Africa (excluding Maghreb) is more recent and very diverse. The three largest com-

Germany, Iceland, Ireland, Liechtenstein, Luxembourg, Monaco, New Zeland, Norway, Sweden, the Netherlands, United Kingdom, United States (2) SE: Andorra, Greece, Italy, Malta, Portugal, San Marino, Spain, the Vatican (3) EE: Albania, Belarus, Bosnia and Herzegovina, Bulgaria, Croatia, Czech Republic, Hungary, Macedonia, Moldova, Poland, Romania, Russia, Serbia and Montenegro, Slovakia, Slovenia, Ukraine (4) AF: Angola, Benin, Botswana, Burkina Faso, Burundi, Cameroon, Cape Verde, Central African Republic, Chad, Comoros, Congo (Brazzaville), Congo (Kinshasa), Ivory Coast, Djibouti, Equatorial Guinea, Eritrea, Ethiopia, Gabon, Gambia, Ghana, Guinea, Guinea-Bissau, Kenya, Lesotho, Liberia, Madagascar, Malawi, Mali, Maurice, Mauritania, Mozambique, Namibia, Niger, Nigeria, Rwanda, Sao Tome and Principe, Senegal, Seychelles, Sierra Leone, Somalia, South Africa, Swaziland, Tanzania, Togo, Uganda, Zambia, Zimbabwe (5) TMM: Algeria, Armenia, Azerbaijan, Bahrain, Cyprus, Egypt, Georgia, Iraq, Israel, Jordan, Kuwait, Lebanon, Libya, Morocco, Oman, Palestine, Qatar, Saudi Arabia, Sudan, Syria, Tunisia, Turkey, United Arab Emirates, Western Sahara, Yemen (6) LA: Antigua and Barbuda, Argentina, Bahamas, Barbados, Belize, Bolivia, Brazil, Chile, Colombia, Costa Rica, Cuba, Dominican Republic, Dominique, Ecuador, El Salvador, grenade, Guatemala, Guyana, Haiti, Honduras, Jamaica, Mexico, Nicaragua, Panama, Paraguay, Peru, Saint Kitts and Nevis, Saint Vincent and the Grenadines, St. Lucia, Suriname, Trinidad and Tobago, Uruguay, Venezuela (7) AS: Brunei Darussalam, Cambodia, China, China (Taiwan), Fiji, Indonesia, Japan, Korea (North), Korea (South), Laos, Malaysia, Mongolia, Myanmar, Papua New Guinea, Philippines, Samoa, Singapore, Solomon Islands, Thailand, Tonga, Vanuatu, Vietnam (8) SCA: Afghanistan, Bangladesh, Bhutan, India, Iran, Kazakhstan, Kyrgyzstan, Maldives, Nepal, Pakistan, Sri Lanka, Tajikistan, Turkmenistan, Uzbekistan. 
munities come from Angola (13\%), Congo (10\%) and Somalia (10\%). Many of their members are political refugees. The Middle East generated a significant number of political refugees too, but most migrants of the sixth group are workers from Turkey (66\%) or Maghreb (20\%). Latin Americans mostly come from Brazil (29\%) and the Dominican Republic, Columbia and Chile (10\% each). The Asian group is similarly heterogeneous, with economic migrants from Thailand (20\%), the Philippines (17\%), China (15\%) or Japan (10\%), and political refugees from Vietnam (19\%) or Cambodia (4\%). The last group of South and Central Asia is clearly dominated by political refugees from Sri-Lanka (59\%). Indians (17\%) and Iranians (12\%) are also sizeable communities.

\subsection{Datasets}

Two datasets are used to investigate the patterns of migrant cultural integration in Switzerland: the Swiss census 2000 and the Swiss Household Panel (SHP). The census covers the 7 million individuals living in Switzerland in 2000. It provides information about the country of birth of an individual, his first and second nationality, and if he is Swiss since birth or not. Individuals born in Switzerland and Swiss since birth are defined as natives. First-generation migrants are born abroad. A second-generation migrant is an individual born in Switzerland, but whose first or second nationality is foreign. ${ }^{7}$

The SHP started in 1999 with 7’799 individuals answering a detailed questionnaire. New observations from the European Survey on Income and Living Conditions (SILC) were added in 2004 and 2005 and increased the total number of observations by wave to $11^{\prime} 565$. The SHP indicates if an individual is born in Switzerland or not, and contains information on the first, second and even third nationality as well as on the first and second nationality of both parents. An individual is defined as a second-generation migrant if he is born in Switzerland and one of his nationalities or one of his parents' nationalities is foreign. If parents are both of foreign origin, the nationality of the father prevails. The slightly different demographic composition of the SHP compared to the census is exposed in table 2. As participating in the SHP survey is more demanding and facultative, first-generation migrants and migrants originating from countries speaking languages other than German, French or Italian are slightly underrepresented.

\footnotetext{
${ }^{7} \mathrm{~A}$ small fraction of second-generation migrants are included in the native group as some of them only have the Swiss nationality since their birth. Those who are only Swiss, but were naturalized and are of unknown origin are not included in either category.
} 


\section{Methods and specifications}

\subsection{List of cultural integration indicators}

The census conducted in 2000 and the SHP allow examining certain objective behaviours and subjective attitudes, which are assumed to reflect the cultural dimension of integration. Integration processes cannot be localized geographically or institutionally, but some units of analysis are especially relevant. School is the first place where all second-generation migrants are exposed to natives and native culture, and school is an important integration mechanism. Secondly, as many adults spend most of their life in the couple (or family), it is of particular interest to observe behaviours in the couple, especially differing patterns of integration between individuals in endogamous couples and partners of mixed couples, where cultural accommodations and compromises are a necessity. Finally, the labour market is the most important mechanism stimulating contacts between natives and migrants outside the household. The list of selected indicators also includes information about the main language of migrants and their attitudes with respect to Switzerland, gender, religious and political issues. Descriptive statistics for natives, first-generation and second-generation migrants are displayed in table 3 .

- Educational attainment: the number of years of education $;^{8}$ the sample is limited to individuals aged 25 years or more.

- Marriage: a dummy equals 1 if an individual is married; the sample is composed of all women aged 18 years or more. Widows are excluded.

- Mixed couple: a dummy equals 1 if a Swiss individual has a partner from a different country of origin; the sample is limited to individuals in a couple, aged 18 years or more. Mixed couples where neither of the partners is Swiss are excluded.

- Age gap between partners: the age difference between the male and female partners; the sample is limited to individuals in a couple, aged 18 years or more.

- Education gap between partners: the difference in number of years of education between the male and female partners; the sample is limited to individuals in a couple, aged 18 years or more.

- Early marriage: a dummy equals 1 if an individual is married; the sample is limited to women aged between 18 and 25 years. Widows are excluded.

\footnotetext{
${ }^{8}$ In the census as well as in the SHP, the available educational variable is categorical. De Coulon et al. (2003) proposed a scale to compute the number of years of education.
} 
- Cohabitation: a dummy equals 1 if an individual lives in cohabitation; the sample is limited to individuals married or living in cohabitation.

- Fertility: the number of children of women aged 40 years or more.

- Divorce: a dummy equals 1 if an individual is divorced; the sample is composed of married and divorced women only, aged 18 years or more.

- Female labour force participation: a dummy equals 1 if a woman is in the labour force; the sample is limited to women aged between 25 and 62 years.

- Main language: a dummy equals 1 if an individual uses one of the four Swiss national languages (French, German, Italian, Romansh) as his main language.

- Feelings towards Switzerland (i) In favor of more equality between Swiss and foreigners ${ }^{9}$ : a dummy equals 1 if the respondent declares to be in favor of more equality. (ii) In favor of opening Swiss traditions ${ }^{10}$ : a dummy equals 1 if the respondent declares to be in favor of opening Swiss traditions to the world.

- Gender attitudes: (i) Child suffers if mother is working ${ }^{11}: 0$ if the respondent does not agree at all with the statement, 10 if she totally agrees; the sample is limited to women. (ii) Women penalized in general $^{12}: 0$ if the respondent does not agree at all with the statement, 10 if he totally agrees; the sample is limited to men.

- Religious attitudes: (i) Participation in religious services ${ }^{13}$ : a dummy equals 1 if the respondent declares she participates in religious services at least occasionally (not only on special occasions). (ii) Prayers $^{14}$ : a dummy equals 1 if the respondent declares he prays at least occasionally.

- Political attitudes: (i) Political affiliation ${ }^{15}$ : 0 if a respondent declares to have extreme left political

\footnotetext{
${ }^{9}$ Original question: Are you in favour of Switzerland offering foreigners the same opportunities as those offered to Swiss citizens, or in favour of Switzerland offering Swiss citizens better opportunities? Possible choices: in favour of equality of opportunities, neither, in favour of better opportunities for Swiss citizens.

${ }^{10}$ Orignal question: Are you in favour of Switzerland opening towards other countries, or in favour of Switzerland defending its traditions? Possible choices: opening towards other countries, neither, defending traditions.

${ }^{11}$ Original question: Please tell me how far you would agree with the statements I am going to read to you now, if 0 means "I completely disagree" and 10 "I completely agree". A pre-school child suffers, if his or her mother works for pay.

${ }^{12}$ Original question: Do you have the feeling that in Switzerland women are penalized compared with men in certain areas, if 0 means "not at all penalized" and 10 "strongly penalized" ?

${ }^{13}$ Original question: How frequently do you take part in religious services? In the beginning, no answer is proposed by the interviewer.

${ }^{14}$ Original question: How frequently do you pray apart from at church or within a religious community? In the beginning, no answer is proposed by the interviewer.

${ }^{15}$ Original question: When they talk about politics, people mention left and right. Personally, where do you position yourself, 0 means "left" and 10 "right" ?
} 
views, 10 if extreme right. (ii) Satisfaction with Swiss democracy ${ }^{16}: 0$ if a respondent does not agree at all with the statement, 10 if he totally agrees.

\subsection{Specifications}

To investigate the evolution of those indicators, two main specifications are used. The first specification compares the outcomes between first and second-generation migrants:

$$
\begin{gathered}
\text { Outcome }_{i}=\sum_{j} \beta_{j} \text { Origin }_{j} * 1 \text { stGeneration } \\
+\sum_{j} \gamma_{j} \text { Origin }_{j} * 2 \text { ndGeneration } \\
+\alpha X_{i}^{\prime}+\varepsilon_{i} .
\end{gathered}
$$

$\beta_{j}$ and $\gamma_{j}$ catch the effect of being a first or second-generation migrant of origin $j$ compared to being a native. The difference between $\beta_{j}$ and $\gamma_{j}$ indicate if the second generation rather tends to reproduce behaviours and attitudes of the first generation or to adapt to those of natives. This first specification implicitily assumes that other factors are common among all observed individuals.

The second specification allows deepening the analysis by introducing additional distinctions. First, as there is no reason to believe that trends in behaviours and attitudes are equally shared among migrants of different origin, outcomes are compared across birth cohorts (born before vs. born after 1970). Second, to investigate if the composition of the couple has an effect on behaviours and attitudes, and if this effect is similar across origin groups, outcomes are compared across types of couples (endogamous vs. mixed couples). Finally, gender differences are also carefully examined using the same specification:

$$
\begin{aligned}
& \text { Outcome }_{i}=\sum_{j} \sum_{k} \beta_{j} \text { Origin }_{j} * \text { Cohort/Couple/Gender } k * 1 \text { stGeneration } \\
& +\sum_{j} \sum_{k} \gamma_{j} \text { Origin }_{j} * \text { Cohort/Couple/Gender }{ }_{k} * 2 \text { ndGeneration } \\
& +\alpha X_{i}^{\prime}+\varepsilon_{i}
\end{aligned}
$$

An OLS estimator is used with continuous indicators and a probit when the outcome is binary. Standard errors are robust. Vector $X$ includes the following controls: age, age squared and the number of years of education. With SHP data, $X$ additionally includes year dummies. With census data, $X$ also controls for four linguistic regions, 16 economic regions and four types of communes. In order not to arbitrarily

\footnotetext{
${ }^{16}$ Original question: Overall, how satisfied are you with the way in which democracy works in our country, if 0 means "not at all satisfied" and 10 "completely satisfied"?
} 
truncate the sample when looking at specific effects tied to intermarriage on a variable that is observable on individuals whether they are in a couple or not (fertility, labour force participation, language), three civil status dummies are included to keep non-married individuals in the sample. ${ }^{17}$ Finally, whereas a gender dummy is generally included in the analysis of attitudes, most regressions looking at behaviours focus strictly on women.

\section{Results}

\subsection{Objective behaviours}

\subsection{1 (i) At school}

According to previous studies, migrants fare rather well in the Swiss educational system. Focusing on a sample of second-generation Italian and Spanish migrants in the cantons of Geneva and Basel, Bolzman and Fibbi (2003) observed that their educational achievements are as good as those of natives. Using 2000 census data on 17 year-old individuals still in the parental household to analyze intergenerational transmission of educational attainment, Bauer and Riphahn (2007) found evidence of higher intergenerational mobility among second-generation migrants. They also found that their achievements or failures are less dependent on their parents' level of education. Fibbi et al. (2005) observed that naturalized migrants are less likely to have a low education level, but this is not the case of non-naturalized first and second-generation migrants (except for Spaniards and Germans). How does the picture change if the scope of the analyis is enlarged to further include non-European migrants?

Table 4 shows the average number of years of education across migrant groups and the gender education gap. This table confirms the impressive educational success of second-generation migrants from Southern Europe that has been documented in previous studies. African women are in a similar situation. However, results also show that the educational achievements of "Secundas" and "Secundos" 18 are not characteristic of all second-generation migrants. Such an outcome might be partly explained by the fact that first-generation migrants are self-selected among the most motivated and capable individuals or by the lack of specific knowledge among migrant parents about the Swiss education system.

Despite the observed negative trend, the gender education gap common to all first-generation groups is reverted among second-generation migrants, with the exception of Western Europeans and Latin Americans,

\footnotetext{
${ }^{17}$ Married natives are the reference group.

${ }^{18}$ In reference to the title of the study of Bolzmann and Fibbi (2003) about second-generation migrants from Southern Europe.
} 
who have the highest average education levels, and Southern European women, who make the largest progress from the first to the second generation.

Results in table 5 (plotted in figure 1.1) confirm that migrant women progress more at school than their male counterparts. It seems that second-generation men from South and Central Asia, Turkey, the Middle East and Maghreb and Eastern Europe remain in a low education equilibrium. The better performance of Western Europeans is not very surprising given the very high education level of the first generation, but the impressive results of second-generation Latin Americans, Africans and the tremendous progress of Southern Europeans support the idea that individuals with a mother tongue close to one of the Swiss national languages (in this case Latin languages) fare better at school.

Table 6 provides more detailed information about cohort effects for both genders (plotted in figures 1.2 and 1.3). A striking result is that the educational level of first-generation migrants is generally declining. Another interesting trend is that second-generation men from Turkey, the Middle East, Maghreb and Eastern Europe that are born after 1970 fare better than those born before 1970.

\subsection{2 (ii) The couples}

Previous studies (Wanner and Fibbi, 2002; Wanner et al., 2005a) looked at the role of family in the migration and integration process. They observed that compared to natives, second-generation migrants tend to remain in the parental household for a longer period and get married after a much shorter cohabitation period with their partner. The overall marriage rate, however, is converging across migrant groups. In their qualitative study on binational couples, Ossipow and Waldis (2003) analyzed the interests and strategies of both intermarried partners. Noticing homogamy and heterogamy exist across many dimensions in any couple, they point to the existence of complementary exchanges in each couple.

In this paper, the analysis is extended to examine the position of women in mixed as well as in endogamous couples. To what extent does origin matter in matching partners? Are women from some groups more likely to contract early marriage and have many children? It is often assumed that migrants from poorer countries are more inclined to form traditional unions with a clear distribution of roles within the household, but to what extent are these clichés supported by facts and do such behaviours persist among second-generation migrants? Also, if some traditional behaviours seem more deeply rooted in specific communities, how do women of these communities behave in mixed couples?

Marriage: Results in table 6 (plotted in figure 1.4) show the marginal effect of origin dummies on the probability of getting married. First-generation women are much more likely to be married than natives. 
Differences among migrant groups hint to the existence of distinct cultural patterns. Western Europeans display the lowest propensity to be married. The decrease in the probability to be married of secondgeneration women to the level of native women points to at least two possible hypotheses. Either cultural differences in the decision to marry disappear or there are other strong incentives (e.g., legal incentives) for first-generation migrants to get married, which do not exist for the second generation. Looking at differences across cohorts reveals that young first-generation migrants are more likely to get married compared to natives, whereas the opposite is true for the second generation. This might be due to more stringent legal conditions for entering Switzerland happening in parallel to a cultural trend to marry less that is not migrantspecific. This is true even for women of Central and South Asia, who remain in a very robust and much more traditional equilibrium characterized by a high probability to be married for first as well as second-generation migrants.

Mixed couples: Intermarriages differ from endogamous marriages because, through the partner and his social network, a migrant is exposed to the native culture in a way that is not possible in an endogamous relationship. Table 8 shows the distribution of endogamous and mixed couples across migrant groups. "Other" couples are composed of partners from different origins, but none of them Swiss. First-generation women intermarry more than their male counterparts. Only women from Turkey, the Middle East, Maghreb, and South and Central Asia do not, and more surprisingly, this is accentuated for second-generation women belonging to these groups. The intermarriage rate of second-generation Western European, Latin American and African women also decreases a lot, but from a very high initial level. Asian women remain in the highest equilibrium despite a slight decrease; Eastern and Southern European second-generation women are the only groups which enter mixed unions more than their mothers.

The marginal effect of origin dummies on the probability to be in a mixed couple reported in table 9 (plotted in figure 1.5) confirm the intuition conveyed by statistics in table 8. First-generation migrant women from Latin America, Asia, Western Europe and Africa are around 50\% more likely than natives to enter a mixed union. Asian women are more likely to choose a Swiss partner than their male counterpart. Women originating from South and Central Asia and Turkey, the Middle East and Maghreb are exceptions in this regard and, more surprisingly, the marginal effect for second-generation women of these groups is negative. Eastern and Southern European women also have a low probability to enter a mixed couple, but it increases for the second generation. It is also interesting to notice that whereas the propensity to choose a native partner rather decreases for second-generation women, it is less the case for men.

This trend also evolves slowly over time: young second-generation female migrants tend to have a lower 
probability to have a relationship with a native man compared to their mothers, but this probability is equal or higher for women born after 1970. The same is true for male migrants, and the magnitude of the change is even higher (figures 1.6 and 1.7). The only exceptions are again women originating from South and Central Asia and Turkey, the Middle East and Maghreb. It is surprising to see that their probability to intermarry decreases for second-generation and younger migrants. This strong preference for endogamy contrasts with trends in other groups.

Different couples - early marriage vs. cohabitation: How do couples form? Early marriage is often associated with a traditional gender role distribution between husband and wife, whereas cohabitating couples are supposedly more fragile, and consist of more independent partners. Table 9 shows most migrant groups (across cohorts and types of couples) have a higher propensity for early marriage compared to natives, especially women from Eastern Europe, Turkey, the Middle East, Maghreb, Central and South Asia. However, this tendency diminishes for all second-generation groups. It seems that migrant groups with the highest probability to get married also do so at a younger age.

Cohabitation is a rather recent phenomenon that has developed as more women started to become economically independent and politically empowered. It is not surprising that first-generation migrants are less likely to choose cohabitation over marriage. However, this propensity increases for the second generation, more so for women from Europe, Latin America and Asia. The coefficients of the post-1970 cohort in table 10 also clearly indicate that there is a cohort-specific change in behaviours concerning cohabitation. Whereas migrants born before 1970 behave more or less alike across generations, second-generation migrants born after 1970 converge to the native baseline, although less rapidly for women of Central and South Asia, Turkey, the Middle East and Maghreb. Mixed couples are much more likely to cohabit than endogamous couples (figure 9). This supports the hypothesis that individuals living as mixed couples may be more liberal, but that legal incentives for first-generation migrants to improve their conditions of stay (or that of their partner) are strong enough to influence the decision to get married.

Partners' differences - age and education gap: Waldis (2008) stresses that heterogamy/homogamy in the couple is not limited to its ethnic dimension, and that complementary/symmetric exchanges happen at different levels in any couple. Table 10 shows three clear trends in relation to the role of age and education as matching factors in the couple. First there seems to be a difference between European women, who are usually slightly younger than their partner, and non-European women, who display larger age gaps. More striking is the fact that non-European first-generation women born after 1970 are significantly younger than their partner (figure 1.9). Age gaps might be explained by the fact that men who migrated alone only find 
a partner later on in their life. Some of them return home to choose a younger partner and then bring them back to Switzerland (Wanner et al., 2005a). The age asymmetry is stronger among migrants born after 1970. However, age gaps in mixed couples are even larger for non-EU first-generation migrants, which supports the hypothesis that access to a permit or citizenship might be part of complementary exchanges happening in mixed couples (Ossipow and Waldis, 2003).

However, the age asymmetry observed in mixed couples is balanced by the fact that partners have almost the same education level. Whereas education seems to only have a small impact on the probability to intermarry, women who intermarry least (from South and Central Asia, Turkey, the Middle East and Maghreb) also have the highest education gaps in endogamous couples. One likely reason for them to intermarry could be to live with a partner that has a similar level of education. In any case, it seems that having similar education levels is a factor in matching partners of different origins, and that eduction represents an important common ground between individuals coming from different horizons (table 12 and figure 1.10).

Fertility: Table 13 reports the marginal effect of origin dummies on fertility. Migrant women generally have more children than natives. Differences tend to be smaller for the second generation. Women from Switzerland, Western and Southern Europe, Latin America and Asia have lower fertility rates than Eastern European women, and women from Turkey, the Middle East and Maghreb, Africa or South and Central Asia have the highest fertility rate. The coefficient of second-generation Asian women is not significant, but they seem to have a fertility pattern that is different from other non-European migrant groups. Second-generation women from the Middle East, Maghreb and Turkey still display the largest differential, but the drop in their fertility rate is also the largest. As expected, the number of years of education has a negative and significant effect on the completed fertility rate.

Although coefficients of the second generation are not significant, columns 3 to 6 in table 13 (figure 1.11) indicate that the fertility rate of women in mixed couples is similar to that of natives. In endogamous couples, first-generation migrants from Africa, Turkey, the Middle East and Maghreb have the most children.

Divorce: Differences in the probability of getting divorced varies across migrant groups, but the groups that tend to be more traditional in marriage also divorce less. Second-generation migrants have a higher divorce rate, but as was observed in cohabitation, it seems that the cultural trend facilitating divorce is not origin-specific, but cohort-specific (table 7 and figure 1.12). 


\subsection{3 (iii) In the labour market}

Wanner et al. (2003) conducted a thorough analysis of factors impacting female labour force participation. They notice three factors specifically influence migrant women's behaviour in this regard: gender roles imported from the origin country, household income and the fact that some permits are related to a preexisting work contract. Although they are more likely to be active in the labour market compared to native women, migrant women originating from some countries display a significantly lower labour force participation rate. Fibbi et al. (2005) also propose an analysis of the probability to be out of the labour force, focusing on individuals aged 23 to 34 years. They do not find evidence of lower labour force participation of migrants compared to natives. Their results do not support the hypothesis that women from "culturally distant" populations have a lower propensity to participate in the labour force. As mentioned before, their report focuses on European migrants, but how does the picture change when the scope of the analysis is enlarged to include non-European migrant women?

Table 14 shows that although there may be cultural differences among first-generation women that lead to varying labour force participation rates, second-generation women almost behave like natives. Migrants from South and Central Asia, Turkey, the Middle East and Maghreb as well as Asia remain least likely to be active in the labour market, sticking to a more traditional gender role distribution.

Looking at cohorts reveals that women originating from Western and Southern Europe are more likely to enter the labour force, especially women born after 1970. This is partly due to the combination of better qualifications and lower fertility rates that were observed earlier. Regression results also show that first-generation women in mixed couples behave like natives in this regard (table 15 and figure 1.13).

\section{$5.2 \quad$ Subjective attitudes}

Besides influencing behaviours, integration processes also affect daily habits, attitudes, values and beliefs of migrants. This section explores the evolution of migrants' use of national languages, of their feelings towards Switzerland, and of their attitudes concerning gender, religious and political issues. SHP data (except for language) is used to investigate cultural integration paths in these subjective dimensions. The smaller sample size reduces the significance of the results obtained. The analysis is therefore mostly limited to the evolution from the first to the second generation. Gender differences are considered only when examining gender attitudes.

Language: Knowledge of one of the four national languages is fundamental not only to succeed at school and in the labour market, but also to understand native culture and develop enriching relationships in the 
host society. It is therefore not surprising that a substantial part of the federal budget devoted to cultural integration was spent on subsidizing organization offering language courses for migrants (OFM, 2006), that mastering one of the national languages is often viewed as a prerequisite for naturalization or that partners in mixed couples often consider it as a fundamental external sign of successful integration (Ossipow and Waldis, 2003).

Results in table 16 (plotted in figure 1.14) show that second-generation migrants are much more likely to declare one of the national languages as their main language. Surprisingly, young second-generation migrants do so more than those born before 1970, whereas no such trend is detectable among first-generation migrants. Different hypotheses could explain this. It might be that the methods to teach languages that are used at Swiss schools have become more effective or that younger second-generation migrants are more willing to adopt a national language as their own.

As expected, differences across migrant groups remain. Western and Southern Europeans are always more likely to adopt a national language of Switzerland as their own, Asians and South and Central Asians display lower probabilities to do so, but it is striking to observe a similarly low probability for Latin Americans, who seem to be much more attached to their mother tongue than Latin migrants from Southern Europe. ${ }^{19}$

First-generation migrants with a Swiss partner have a slightly higher probability to adopt a national language as their own than those in endogamous couples. However, the picture is more blurred for secondgeneration migrants, as African and Latin American migrants are visibly rather keen to keeping their mother tongue.

Feelings towards Switzerland: One could assume that in a non-discriminatory society, no one would request more equality between natives and foreigners. Table 17 shows that all migrants living in Switzerland are in favor of more equality compared to natives. This trend is stronger among first-generation than among second-generation migrants, except for those likely to have darker skin color or those likely to be identified as Muslims (South and Central Asians, Africans and individuals originating from Turkey, the Middle East and Maghreb), who feel more could be done to facilitate their integration in the Swiss society. Interestingly, migrants of the younger cohort have a more pronounced opinion than those born before 1970. When asked whether they are in favor of opening Swiss traditions to world influence, results look similar (table 18 and figure 1.15).

Gender attitudes: In relation to gender attitudes, it appears that more conservative behaviours of first-generation migrants are in line with their more conservative subjective attitudes. Results in table 19

\footnotetext{
${ }^{19}$ As Italian is a national language, the author tested this by keeping migrants of Italian origin out of the sample. Results are available upon request.
} 
show how women internalize the traditional role of mothers. Compared to natives, migrant women are likely to believe children suffer when the mother is working. Western European women are the only exception. It might also be that as more migrant women live in precarious conditions, they feel strongly that working would harm their children (e.g., because they cannot afford to leave their children in a private day-nursery) Results in table 20 (plotted in figure 1.16) show how sensitive men are to the specific discriminations women are suffering from. Male migrants from Western, Southern Europe and Latin America are the only ones to be more sensitive to this issue than native men. Looking at the second generation, it is difficult to identify meaningful differences. It might be that attitudes of second-generation migrants concerning gender issues converge relatively fast with the Swiss average, while behaviours need more time to change. ${ }^{20}$

Religious attitudes: Religious attitudes are also losing their intensity over time. Table 21 shows that first-generation migrants are more likely to visit places of worship than natives. More assiduous attendance of religious offices could be explained by the fact that it is a social act strengthening the cohesion of communities. The hypothesis that religion fulfills a social rather than a spiritual function in migrant communities is supported by the fact that migrants are not more inclined to pray than natives (table 22 and figure 1.17), and that second-generation migrants are not more religious than natives. Interestingly, migrants from Turkey, the Middle East and Maghreb are very close to natives in terms of their propensity to attend religious offices or to pray. The qualitative study of Gianni et al. (2005) on Muslims in Switzerland draws similar conclusions.

Political attitudes: Finally, the analysis of political attitudes shows that all migrants are more leaning to the left than the more conservative Swiss majority, except for second-generation Asian and African migrants (table 23). Their coefficients, however, are not significant. It also appears that migrants from countries with democratic traditions (Western and Southern Europeans, Latin Americans) are less likely to express satisfaction with the Swiss democracy than migrants coming from regions were political regimes are mostly undemocratic (table 24 and figure 1.18). Natives seem to be the most critical of their own political system.

\footnotetext{
${ }^{20}$ See results on behaviours in the couple, and the findings of Wimmer (2004) that were cited above.
} 


\section{Discussion}

The main findings of this first paper can be summarized as follows:

- The evolution of selected indicators from the first to the second generation clearly shows that cultural integration processes are at work in all migrant communities. However, significant differences remain between behaviours and attitudes across migrant groups:

- At school, men from South and Central Asia, Turkey, the Middle East and Maghreb and Eastern Europe seem stuck in a low educational equilibrium. Young second-generation migrants, however, have improved their performances and the gender gap is declining, due to the progresses made by second-generation women. Differences across groups are especially obvious when looking at the position of women in the couple. Migrant women from South and Central Asia, Turkey, the Middle East and Maghreb are least likely to intermarry, even less than their male counterparts, and they display more traditional behaviours in most of the indicators examined. In the labour market, migrant women are slightly less likely to be active, but this difference disappears in the second generation, except for Asian migrants.

- Patterns of migrants' subjective attitudes are more difficult to identify. Results show "linguistically distant" migrants are less likely to declare one of the four national languages as their main language. Migrants' feelings toward Switzerland show that they perceive discriminations more strongly in comparison to natives, particularly migrants likely to have darker skin color or those likely to be identified as Muslims. The more conservative behaviours of first-generation migrants in the couple are in line with their more conservative subjective gender attitudes. It might be that attitudes evolve more rapidly in a new social environment than behaviours do. Minor differences in religious attitudes vanish at the second generation, which supports the hypothesis that religious office attendance fulfils a social (and to some extent an economic) function rather than a spiritual function. Concerning political attitudes, migrants seem to be more satisfied with Swiss democracy, and they lean more to the left than natives.

- The general convergence pattern observed from the first to the second generation has no match across cohorts. Only a few cohort-specific cultural trends could be identified (see section on cohabitation or divorce). It is therefore not possible to claim that younger migrants integrate better or worse than migrants born before 1970 . 
- Convergence is particularly at work in mixed couples, where first-generation women of all origin already adopt native behaviours (including women from South and Central Asia, from Turkey, the Middle East and Maghreb), stressing the weakness of the "cultural distance" argument. First and second-generation migrants in endogamous couples reproduce more traditional behaviours. Although it is not possible to capture individual traits that impact on the partner choice, this analysis leads to the conclusion that the interplay between household members (given the characteristics of individuals, of the household and of their social environment) or "household dynamics" has an important role in integration processes.

- Education always has the expected significant effect on examined indicators. Its impact is non-negligible on fertility, but it is modest for most other indicators.

The review of the selected indicators reveals that cultural integration processes, which are at work in various ways in the different groups, contribute to overall convergence. The most striking and lasting differences that are observed across groups do not pertain to educational achievement, religious or political attitudes, but to gender-related attitudes and even more to gender-related behaviours. Differences are more pronounced in endogamous couples in general, specifically for women from South and Central Asia, Turkey, the Middle East and Maghreb.

As such, the decision to marry at an early age or to live in cohabitation, age and education gaps between partners, the preferred number of children and opinions on gender issues are private matters. However, they also influence the position women have in the household and in society. Previous studies called to focus less on individuals in migration studies and more on families, as they are key in socializing second-generation migrants on whom most policy efforts are targeted (Wanner and Fibbi, 2002). Others observed that some migrant groups are more inclined to reproduce traditional family structures and relationships (Moret et al., 2007) and have very pronounced gender attitudes that may be exacerbated by the destabilizing effect of migration on families (Gianni et al., 2005).

The findings presented in this paper lead to the recommendation to better take into account migrationrelated gender issues and migration-specific "household dynamics" in the design of future cultural integration policies. It is on purpose that term "household dynymics" is preferred over "family." First, the term family evokes the image of married couples with children, whereas a household is not associated with any particular structure (traditional or not). Secondly, implicitly or explicitly insisting on the unity and intergenerational solidarity existing in (migrant) families conceals the fact that migrant households may be confronted by specific problems. Constraints imposed by migration require specific household arrangements, which facilitate the division of labour among household members and a clearer distribution of gender roles within the couple. 
Those constraints can intensify gender issues, which also exist, although to a different degree, among native couples. Education, labour market and other policies can and should be used to influence the integration of migrants in Swiss society, but more targeted programmes (next to existing language courses, civic and other programmes) and policies could be designed to address gender issues, which arise out of or are exacerbated by migration and migration-specific dynamics developing in migrant households.

Such programmes should not so much aim at informing migrants about what is considered in conformity with Swiss values concerning gender or family, but about informing them of their individual rights. Moreover, programmes should support associations and organizations which contribute to empower migrants in general (when confronted by the precariousness of their legal situation, the diminished job security, discrimination, etc.) and migrant women in particular (when confronted by situations of domestic violence, forced marriage, etc.) to exercise their rights. Given the ease with which extremist parties exploit such problems and the disproportionate emphasis cultural integration issues are given in the public debate, it is important that decent financial support is granted by lawmakers to actors involved in such work. Finally, the challenging situation that some migrant women face should not conceal that, although gender equality is claimed to be a fundamental value of Western societies, it is a relatively recent "acquis," particularly in Switzerland, ${ }^{21}$ and that much remains to be done.

\footnotetext{
${ }^{21}$ The emancipation of women is particularly recent in Switzerland. The fact that Switzerland was not militarily involved in any of the World Wars of the last century delayed the entry of women in the labour market and their access to economic independence compared to other industrialized countries. This and other factors in turn slowed down the acquisition of the voting rights for women, who obtained this political right only in 1971 at the federal level. In 1990, the Swiss federal court finally ruled that the exclusion of women in cantonal polls in Appenzell Inner Rhodes was unconstitutional.
} 


\section{Bibliography}

ALBA, R., and V. NEE (1997): "Rethinking Assimilation Theory for a New Era of Immigration," International Migration Review, vol. 31, 826-874.

BAUER, P., and R. T. RIPHAHN (2007): "Heterogeneity in the Intergenerational Transmission of Educational Attainment: Evidence from Switzerland on Natives and Second-Generation Immigrants," Population Economics, vol. 20, 121-148.

BISIN, A., E. PATACCHINI, T. VERDIER, and Y. ZENOU (2006): "Bend It Like Beckham': Identity, Socialization and Assimilation," Center for Economic Policy Research DP No. 5662.

— (2008): “Are Muslim Immigrants Different in Terms of Cultural Integration?," Journal of the European Economic Association, vol. 6(2-3), 445-456.

BISIN, A., G. TOPA, and T. VERDIER (2004): "Religious Intermarriage and Socialization in the United States," Journal of Political Economy, vol. 112, 615-664.

BOLZMANN, C., and R. FIBBI (2003): Secondas Secondos : Le processus d'intégration des jeunes adultes issus de la migration espagnole et italienne en Suisse, Zürich: Seismo.

BOLZMANN, C., R. FIBBI, and M. VIAL (2003): "Que sont-ils devenus? Le processus d'insertion des adultes issus de la migration," in: Wicker, Hans-Rudolf, et al. (Ed.), Les migrations et la Suisse : résultats du Programme national de recherche "Migrations et relations interculturelles," Zürich: Seismo, 434-459.

CATTACIN, S., and K. BÜHLENT (2005): "Le développement des mesures d'intégration de la population migrante sur le plan local en Suisse," in: Mahnig, Hans, et al. (Ed.), Histoire de la politique de migration, d'asile et d'intégration en Suisse depuis 1948, Zürich: Seismo, 288-320.

D'AMATO, G. (2008): Mit dem Fremden politisieren. Rechtspopulismus und Migrationspolitik in der Schweiz seit den 1960er Jahren, Zürich: Chronos Verlag.

FIBBI, R., P. WANNER, and M. LERCH (2005): "Processus de naturalisation et caractéristiques socio- 
économiques des jeunes issus de la migration," in: Fibbi, Rosita, et al. (Ed.), L'intégration des populations issues de l'immigration en Suisse: personnes naturalisées et deuxième génération, Neuchâtel: OFS, 9-60.

GEORGIADIS, A., and A. MANNING (2011): "Change and Continuity among Minority Communities in Britain," Journal of Population Economics, vol. 24(2), 541-568.

GIANNI, M., M. SCHNEUWLY PURDIE, S. LATHION, and M. JENNY (2005): Vie musulmane en Suisse, Bern: Commission fédérale des étrangers.

HENRY, P., G. GAUDARD, and P. ARBENZ (1995): La Suisse, terre d'asile, Bienne: Libertas suisse.

KOHLER, P (2009): "Les signes avant-coureurs de l'islamophobie en Suisse," Le Temps, 9 December 2009.

KOHLER, P. (2010): "La double discrimination des musulmans sur le marché de l'emploi," in: Tangram, Bern: Eidgenössische Kommission gengen Rassismus, vol. 25, 93-98.

KOHLER, P. (forthcoming): "Cultural Integration in Switzerland," in: Algan, Yann, et al. (Ed.), Cultural Integration of Immigrants in Europe, Oxford: Oxford University Press, number 9780199660094.

MAHNIG, H., and E. PIGUET (2003): "La politique suisse d'immigration de 1948 à 1998: évolution et effets," in: Wicker, Hans-Rudolf, et al. (Ed.), Les migrations et la Suisse : résultats du Programme national de recherche "Migrations et relations interculturelles," Zürich: Seismo, 63-103.

MORET, J., D. EFI ONAYI, and F. STANTS (2007): Die Srilankische Diaspora in der Schweiz, Neuchâtel: SFM.

OFM, Office Fédéral des Migrations (2006): Problèmes d'intégration des ressortissants étrangers en Suisse: identification des faits, des causes, des groupes à risque, des mesures existantes ainsi que des mesures à prendre en matière de politique d'intégration, Bern: OFM.

OFS, Office Fédéral de la Statistique (2005): Structure de la population, langue principale et religion, Neuchâtel: OFS.

OSSIPOW, L., and B. WALDIS (2003): "Couples binationaux et sociétés multiculturelles," in: Wicker, 
Hans-Rudolf, et al. (Ed.), Les migrations et la Suisse : résultats du Programme national de recherche "Migrations et relations interculturelles," Zürich: Seismo, 375-403.

PIGUET, E. (2009): L'immigration en Suisse: 60 ans d'entrouverture, Lausanne: Presses Polytechniques et Universitaires Romandes.

RIANO, Y., and D. WASTL-WALTER (2006): "Immigration Policies, State Discourses on Foreigners, and the Politics of Identity in Switzerland," Environment and Planning, vol. 38, 1693-1713.

WANNER, P. (2004): Migration et intégration : populations étrangères en Suisse, Neuchâtel: OFS.

WANNER, P., A. GABADINHO, and A. FERRARI (2003): La participation des femmes au marché du travail, Bern: OFAS.

WANNER, P., A. NEUBAUER, and J. MORET (2002): Caractéristiques de vie et d'intégration des populations issues de l'immigration: une analyse des données du panel suisse des ménages 1999-2000, Neûchatel: SFM.

WANNER, P., and R. FIBBI (2002): Familles et migration, familles en migration," in: Wanner, Philippe, et al. (Ed.), Etudes sur la situation des familles migrantes et recommandations de la Commission fédérale de coordination pour les questions familiales, Bern: COFF, 9-50.

WANNER, P., L. MATHIAS, and R. FIBBI (2005a): Familles et migration : le rôle de la famille sur les flux migratoires, Neuchâtel: OFS.

WANNER, P., M. PECORARO, and R. FIBBI (2005b): "Femmes étrangères et marché du travail," in: Haug, Werner, et al. (Ed.), Migrants et marché du travail : compétences et insertion professionnelle des personnes d'origine étrangère en Suisse, Neuchâtel: OFS, 17-38.

WICKER, H.-R. (2003): "Introduction: migration, politique de migration et recherche sur la migration," in: Wicker, Hans-Rudolf, et al. (Ed.), Les migrations et la Suisse : résultats du Programme national de recherche "Migrations et relations interculturelles," Zürich: Seismo, 11-62.

WICKER, H.-R., FIBBI, R. and W. HAUG (2003): Les migrations et la Suisse : résultats du Programme 
national de recherche "Migrations et relations interculturelles," Zürich: Seismo.

WIMMER, A. (2004): "Does Ethnicity Matter? Everyday Group Formation in Three Swiss Immigrant Neighbourhoods," Ethnic and Racial Studies, vol. 27, 1-36.

- (2008): "The Making and Unmaking of Ethnic Boundaries: A Multilevel Process Theory," American Journal of Sociology, vol. 113, 970-1022.

WINLOW, H. (2006): "Mapping Moral Geographies: W. Z. Ripley's Races of Europe and the United States," Annals of the Association of American Geographers, vol. 96(1), 119-141. 


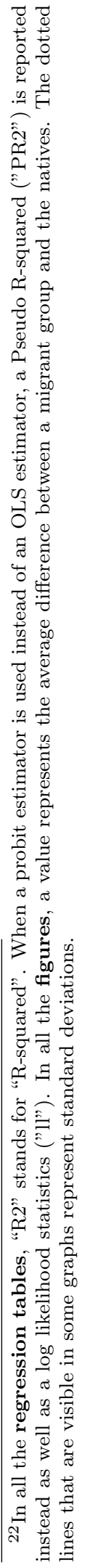




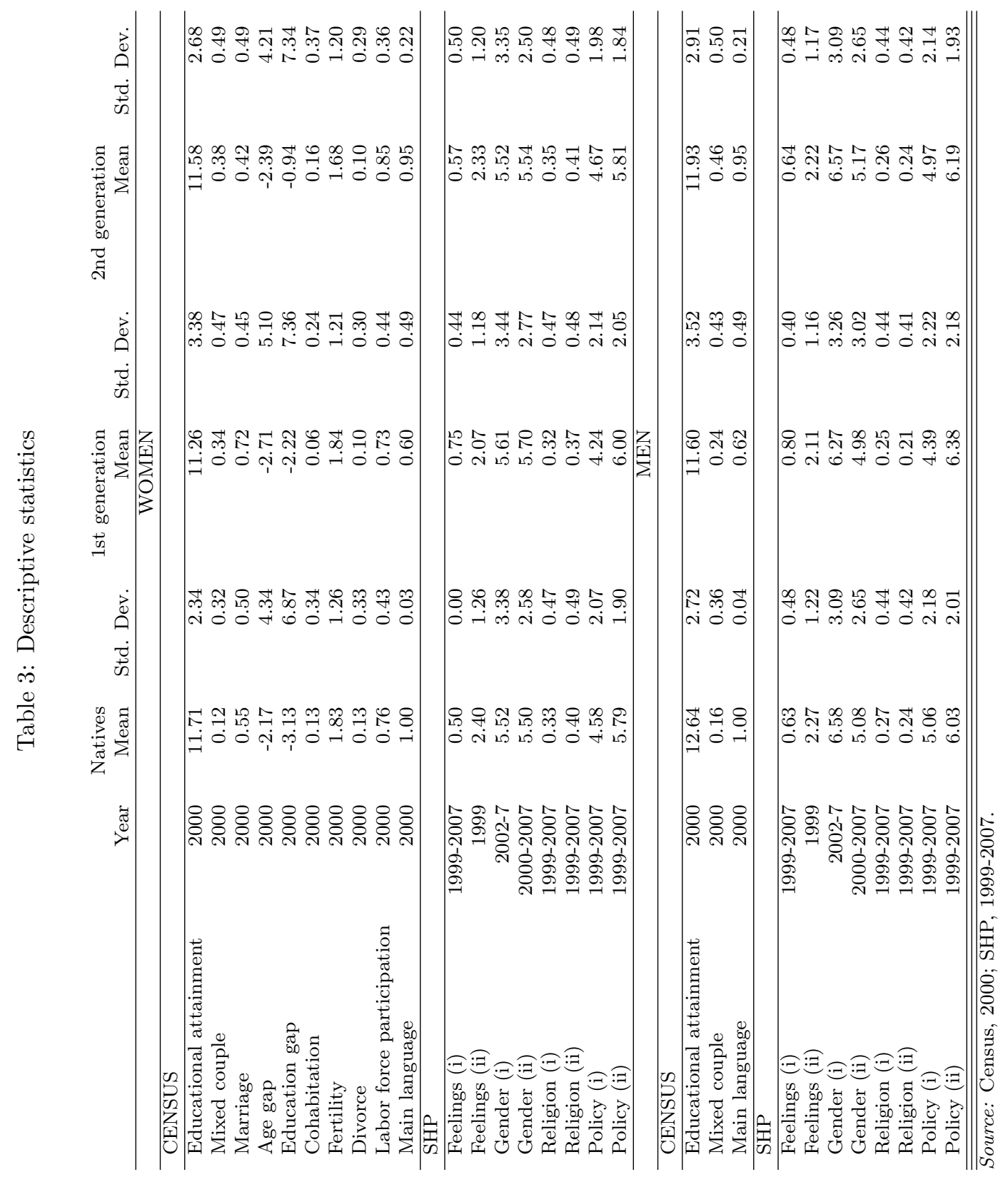




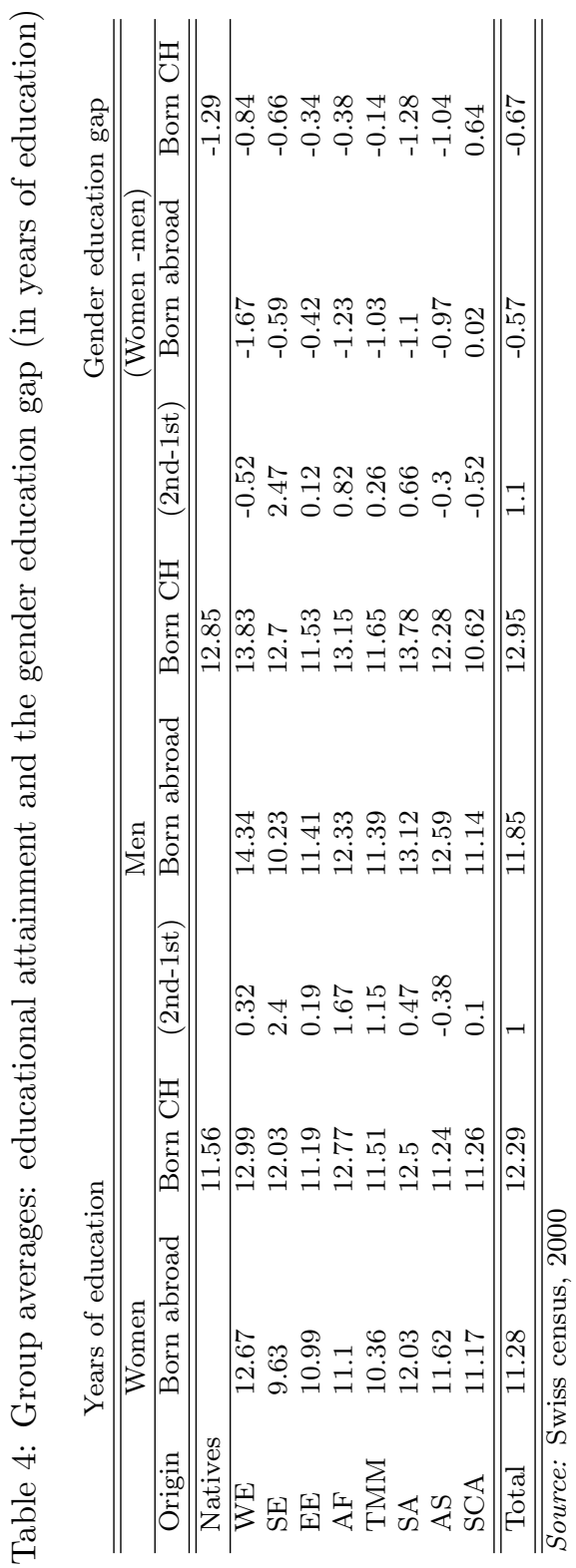


Table 5: Educational attainment (I)

\begin{tabular}{|c|c|c|c|c|}
\hline & Women & & Men & \\
\hline Origin & $1 \mathrm{st}$ & 2nd & $\overline{~ 1 s t}$ & 2nd \\
\hline WE & $\begin{array}{l}0.928^{* * *} \\
(0.006)\end{array}$ & $\begin{array}{l}0.815^{* * *} \\
(0.014)\end{array}$ & $\begin{array}{l}1.235^{* * *} \\
(0.007)\end{array}$ & $\begin{array}{l}0.367^{* * *} \\
(0.015)\end{array}$ \\
\hline $\mathrm{SE}$ & $\begin{array}{l}-2.304^{* * *} \\
(0.007)\end{array}$ & $\begin{array}{l}-0.255^{* * * *} \\
(0.010)\end{array}$ & $\begin{array}{l}-2.973^{* * *} \\
(0.006)\end{array}$ & $\begin{array}{l}-0.856^{* * * *} \\
(0.010)\end{array}$ \\
\hline $\mathrm{EE}$ & $\begin{array}{l}-1.041^{* * *} \\
(0.008)\end{array}$ & $\begin{array}{l}-1.076^{* * *} \\
(0.040)\end{array}$ & $\begin{array}{l}-1.796^{* * *} \\
(0.008)\end{array}$ & $\begin{array}{l}-1.902^{* * *} \\
(0.040)\end{array}$ \\
\hline $\mathrm{AF}$ & $\begin{array}{l}-1.266^{* * *} \\
(0.024)\end{array}$ & $\begin{array}{l}0.412^{* * *} \\
(0.141)\end{array}$ & $\begin{array}{l}-1.304^{* * *} \\
(0.025)\end{array}$ & $\begin{array}{c}-0.266^{*} \\
(0.160)\end{array}$ \\
\hline TMM & $\begin{array}{l}-1.855^{* * *} \\
(0.015)\end{array}$ & $\begin{array}{l}-0.828^{* * *} \\
(0.051)\end{array}$ & $\begin{array}{l}-2.036^{* * *} \\
(0.013)\end{array}$ & $\begin{array}{l}-1.910^{* * *} \\
(0.054)\end{array}$ \\
\hline LA & $\begin{array}{l}-0.311^{* * *} \\
(0.016)\end{array}$ & $\begin{array}{l}0.272^{* *} \\
(0.108)\end{array}$ & $\begin{array}{l}-0.468^{* * *} \\
(0.026)\end{array}$ & $\begin{array}{l}0.473^{* * *} \\
(0.119)\end{array}$ \\
\hline AS & $\begin{array}{l}-0.607^{* * *} \\
(0.016)\end{array}$ & $\begin{array}{l}-1.031^{* * *} \\
(0.160)\end{array}$ & $\begin{array}{l}-0.844^{* * *} \\
(0.026)\end{array}$ & $\begin{array}{l}-1.171^{* * *} \\
(0.202)\end{array}$ \\
\hline SCA & $\begin{array}{l}-1.150^{* * *} \\
(0.025)\end{array}$ & $\begin{array}{l}-0.983^{* * *} \\
(0.132)\end{array}$ & $\begin{array}{l}-2.324^{* * *} \\
(0.020)\end{array}$ & $\begin{array}{l}-2.983^{* * *} \\
(0.147)\end{array}$ \\
\hline Gender & $\begin{array}{l}-1.202^{* * *} \\
(0.002)\end{array}$ & & & \\
\hline Observations & 4460422 & & & \\
\hline $\mathrm{R} 2$ & 0.18 & & & \\
\hline
\end{tabular}

Table 6: Educational attainment (II)

\begin{tabular}{|c|c|c|c|c|c|c|c|c|}
\hline \multirow[b]{3}{*}{ Origin } & \multicolumn{4}{|l|}{ Women } & \multicolumn{4}{|l|}{ Men } \\
\hline & Pre-1970 & & Post-1970 & & Pre-1970 & & Post-1970 & \\
\hline & $1 \mathrm{st}$ & 2nd & $1 \mathrm{st}$ & 2nd & $1 \mathrm{st}$ & 2nd & 1 st & 2nd \\
\hline WE & $\begin{array}{l}0.926^{* * *} \\
(0.006)\end{array}$ & $\begin{array}{l}0.716^{* * *} \\
(0.016)\end{array}$ & $\begin{array}{l}1.069 * * * \\
(0.020)\end{array}$ & $\begin{array}{l}0.533^{* * *} \\
(0.029)\end{array}$ & $\begin{array}{l}1.299^{* * *} \\
(0.008)\end{array}$ & $\begin{array}{l}0.621^{* * *} \\
(0.019)\end{array}$ & $\begin{array}{l}0.933^{* * *} \\
(0.025)\end{array}$ & $\begin{array}{l}0.294^{* * *} \\
(0.033)\end{array}$ \\
\hline $\mathrm{SE}$ & $\begin{array}{l}-2.330^{* * *} \\
(0.007)\end{array}$ & $\begin{array}{l}-0.424^{* * *} \\
(0.012)\end{array}$ & $\begin{array}{l}-2.458^{* * *} \\
(0.023)\end{array}$ & $\begin{array}{l}-0.555^{* * *} \\
(0.018)\end{array}$ & $\begin{array}{l}-2.948^{* * *} \\
(0.007)\end{array}$ & $\begin{array}{l}-0.621^{* * *} \\
(0.014)\end{array}$ & $\begin{array}{l}-2.876^{* * *} \\
(0.025)\end{array}$ & $\begin{array}{l}-0.801^{* * *} \\
(0.019)\end{array}$ \\
\hline $\mathrm{EE}$ & $\begin{array}{l}-0.979^{* * *} \\
(0.008)\end{array}$ & $\begin{array}{l}-1.822^{* * *} \\
(0.052)\end{array}$ & $\begin{array}{l}-1.771^{* * *} \\
(0.019)\end{array}$ & $\begin{array}{l}-0.676^{* * *} \\
(0.062)\end{array}$ & $\begin{array}{l}-1.592^{* * *} \\
(0.009)\end{array}$ & $\begin{array}{l}-2.196^{* * *} \\
(0.056)\end{array}$ & $\begin{array}{l}-2.569^{* * *} \\
(0.024)\end{array}$ & $\begin{array}{l}-1.110^{* * *} \\
(0.073)\end{array}$ \\
\hline $\mathrm{AF}$ & $\begin{array}{l}-1.274^{* * *} \\
(0.025)\end{array}$ & $\begin{array}{l}0.269^{*} \\
(0.158)\end{array}$ & $\begin{array}{l}-2.114^{* * *} \\
(0.050)\end{array}$ & $\begin{array}{l}0.163 \\
(0.277)\end{array}$ & $\begin{array}{l}-0.829^{* * * *} \\
(0.029)\end{array}$ & $\begin{array}{r}-0.0861 \\
(0.203)\end{array}$ & $\begin{array}{l}-2.279^{* * *} \\
(0.062)\end{array}$ & $\begin{array}{c}-0.0242 \\
(0.346)\end{array}$ \\
\hline TMM & $\begin{array}{l}-1.905^{* * *} \\
(0.016)\end{array}$ & $\begin{array}{l}-0.840^{* * *} \\
(0.064)\end{array}$ & $\begin{array}{l}-2.424^{* * *} \\
(0.034)\end{array}$ & $\begin{array}{l}-1.347^{* * *} \\
(0.083)\end{array}$ & $\begin{array}{l}-1.820^{* * * *} \\
(0.015)\end{array}$ & $\begin{array}{l}-2.018^{* * *} \\
(0.084)\end{array}$ & $\begin{array}{l}-2.516^{* * *} \\
(0.035)\end{array}$ & $\begin{array}{l}-1.440^{* * * *} \\
(0.089)\end{array}$ \\
\hline LA & $\begin{array}{l}-0.208^{* * *} \\
(0.017)\end{array}$ & $\begin{array}{l}0.111 \\
(0.118)\end{array}$ & $\begin{array}{l}-1.541^{* * *} \\
(0.037)\end{array}$ & $\begin{array}{l}0.368^{*} \\
(0.222)\end{array}$ & $\begin{array}{c}-0.0217 \\
(0.031)\end{array}$ & $\begin{array}{l}0.678^{* * *} \\
(0.144)\end{array}$ & $\begin{array}{l}-1.472^{* * *} \\
(0.067)\end{array}$ & $\begin{array}{l}0.333 \\
(0.308)\end{array}$ \\
\hline $\mathrm{AS}$ & $\begin{array}{l}-0.611^{* * *} \\
(0.017)\end{array}$ & $\begin{array}{l}-1.263^{* * *} \\
(0.178)\end{array}$ & $\begin{array}{l}-1.325^{* * *} \\
(0.038)\end{array}$ & $\begin{array}{l}-0.998^{* * *} \\
(0.319)\end{array}$ & $\begin{array}{l}-0.705^{* * *} \\
(0.030)\end{array}$ & $\begin{array}{l}-1.607^{* * *} \\
(0.267)\end{array}$ & $\begin{array}{l}-0.889^{* * *} \\
(0.067)\end{array}$ & $\begin{array}{l}0.215 \\
(0.395)\end{array}$ \\
\hline $\mathrm{SCA}$ & $\begin{array}{l}-0.948^{* * *} \\
(0.027)\end{array}$ & $\begin{array}{l}-0.764^{* * *} \\
(0.136)\end{array}$ & $\begin{array}{l}-2.444^{* * *} \\
(0.050)\end{array}$ & $\begin{array}{l}-2.911^{* * *} \\
(0.344)\end{array}$ & $\begin{array}{l}-2.032^{* * *} \\
(0.023)\end{array}$ & $\begin{array}{l}-2.846^{* * *} \\
(0.191)\end{array}$ & $\begin{array}{l}-3.172^{* * *} \\
(0.051)\end{array}$ & $\begin{array}{l}-3.046^{* * *} \\
(0.294)\end{array}$ \\
\hline Observations & 2255991 & & & & 2120707 & & & \\
\hline $\mathrm{R} 2$ & 0.17 & & & & 0.13 & & & \\
\hline
\end{tabular}


Table 7: Marriage and divorce

\begin{tabular}{|c|c|c|c|c|c|c|}
\hline \multirow{2}{*}{\multicolumn{3}{|c|}{$\frac{\text { Marriage }}{\text { All }}$}} & \multicolumn{4}{|l|}{ Divorce } \\
\hline & & & Pre-1970 & & Post-1970 & \\
\hline Origin & 1 1st & 2nd & 1st & 2nd & 1st & 2nd \\
\hline$\overline{\mathrm{WE}}$ & $\begin{array}{l}0.0573^{* * *} \\
(0.001)\end{array}$ & $\begin{array}{l}-0.0218^{* * *} \\
(0.002)\end{array}$ & $\begin{array}{l}0.00793^{* * *} \\
(0.001)\end{array}$ & $\begin{array}{l}-0.0504^{* * *} \\
(0.002)\end{array}$ & $\begin{array}{l}0.0196^{* * *} \\
(0.002)\end{array}$ & $\begin{array}{l}-0.0301^{* * *} \\
(0.005)\end{array}$ \\
\hline $\mathrm{SE}$ & $\begin{array}{l}0.195^{* * *} \\
(0.001)\end{array}$ & $\begin{array}{l}0.0825^{* * *} \\
(0.001)\end{array}$ & $\begin{array}{l}-0.0582^{* * *} \\
(0.001)\end{array}$ & $\begin{array}{l}-0.0677^{* * *} \\
(0.002)\end{array}$ & $\begin{array}{l}-0.0288^{* * *} \\
(0.001)\end{array}$ & $\begin{array}{l}-0.0342^{* * *} \\
(0.002)\end{array}$ \\
\hline $\mathrm{EE}$ & $\begin{array}{l}0.252^{* * *} \\
(0.001)\end{array}$ & $\begin{array}{l}0.127^{* * *} \\
(0.005)\end{array}$ & $\begin{array}{l}-0.0292^{* * *} \\
(0.001)\end{array}$ & $\begin{array}{l}-0.0730^{* * *} \\
(0.001)\end{array}$ & $\begin{array}{l}-0.0530 * * * \\
(0.005)\end{array}$ & $\begin{array}{l}-0.0343^{* * *} \\
(0.008)\end{array}$ \\
\hline $\mathrm{AF}$ & $\begin{array}{l}0.179 * * * \\
(0.003)\end{array}$ & $\begin{array}{l}0.102^{* * *} \\
(0.020)\end{array}$ & $\begin{array}{l}-0.00420 \\
(0.003)\end{array}$ & $\begin{array}{l}-0.0601^{* * *} \\
(0.004)\end{array}$ & $\begin{array}{l}-0.00989 \\
(0.020)\end{array}$ & $\begin{array}{l}-0.0859^{* * *} \\
(0.023)\end{array}$ \\
\hline TMM & $\begin{array}{l}0.253^{* * *} \\
(0.001)\end{array}$ & $\begin{array}{l}0.151^{* * *} \\
(0.005)\end{array}$ & $\begin{array}{l}-0.0347^{* * *} \\
(0.001)\end{array}$ & $\begin{array}{l}-0.0608^{* * *} \\
(0.002)\end{array}$ & $\begin{array}{l}-0.00561 \\
(0.008)\end{array}$ & $\begin{array}{r}-0.0101 \\
(0.010)\end{array}$ \\
\hline LA & $\begin{array}{l}0.230^{* * *} \\
(0.001)\end{array}$ & $\begin{array}{l}0.0532^{* * *} \\
(0.016)\end{array}$ & $\begin{array}{l}-0.0102^{* * *} \\
(0.002)\end{array}$ & $\begin{array}{l}-0.0567^{* * *} \\
(0.003)\end{array}$ & $\begin{array}{l}0.0271 \\
(0.017)\end{array}$ & $\begin{array}{c}-0.0469 \\
(0.030)\end{array}$ \\
\hline AS & $\begin{array}{l}0.201 * * * \\
(0.002)\end{array}$ & $\begin{array}{l}0.0680^{* * * *} \\
(0.023)\end{array}$ & $\begin{array}{l}-0.0232^{* * *} \\
(0.002)\end{array}$ & $\begin{array}{l}-0.0627^{* * *} \\
(0.003)\end{array}$ & $\begin{array}{l}-0.0394^{* *} \\
(0.019)\end{array}$ & $\begin{array}{l}-0.0722^{*} \\
(0.037)\end{array}$ \\
\hline SCA & $\begin{array}{l}0.274^{* * *} \\
(0.002)\end{array}$ & $\begin{array}{l}0.250^{* * *} * \\
(0.012)\end{array}$ & $\begin{array}{l}-0.0721^{* * *} \\
(0.002)\end{array}$ & $\begin{array}{l}-0.0988^{* * * *} \\
(0.002)\end{array}$ & $\begin{array}{l}-0.0894^{* * *} \\
(0.007)\end{array}$ & $\begin{array}{l}-0.0908^{* * *} \\
(0.01)\end{array}$ \\
\hline Education & $\begin{array}{l}-0.010^{* * *} \\
(0.0001)\end{array}$ & & $\begin{array}{l}-4.72 \mathrm{e}-05 \\
(0.0001)\end{array}$ & & & \\
\hline Observations & 2276316 & & 1655090 & & & \\
\hline PR2 & 0.18 & & 0.035 & & & \\
\hline 11 & $-1.217 \mathrm{e}+06$ & & -585480 & & & \\
\hline
\end{tabular}

Source: SHP, 1999-2007; Standard errors in parentheses; ${ }^{* * *} \mathrm{p}<0.01,{ }^{* *} \mathrm{p}<0.05,{ }^{*} \mathrm{p}<0.1$. 


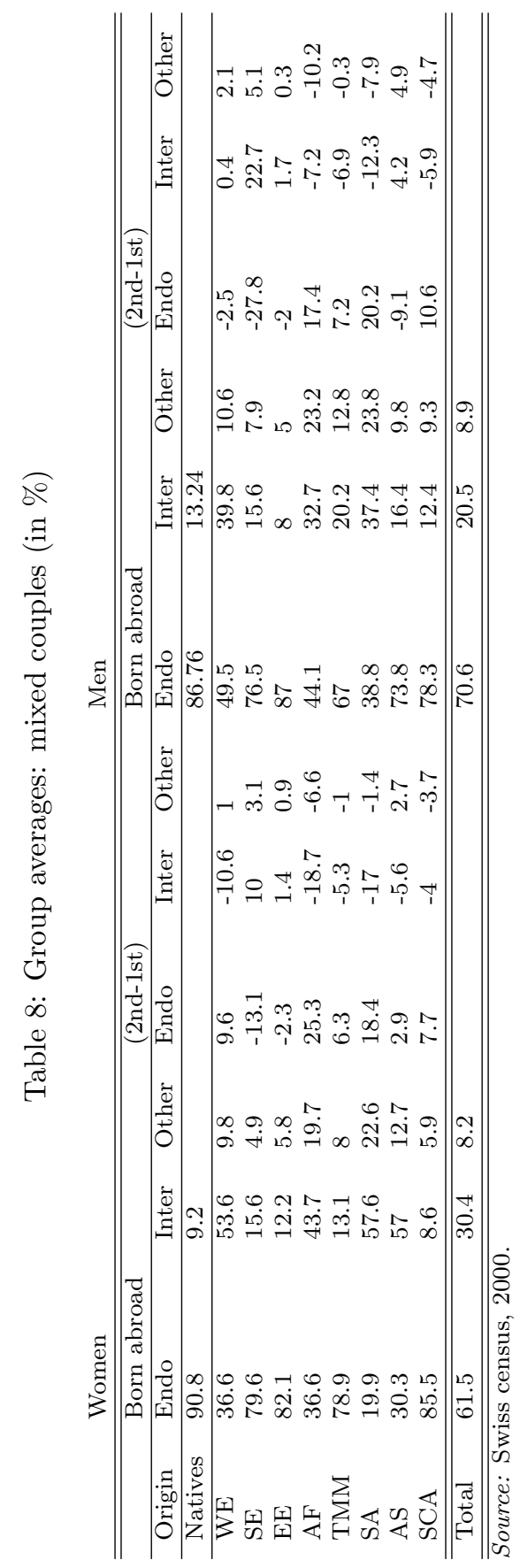


Table 9: Mixed couples

\begin{tabular}{|c|c|c|c|c|c|c|}
\hline \multirow{2}{*}{$\overline{\text { Origin }}$} & \multicolumn{2}{|l|}{ All } & \multicolumn{2}{|l|}{ Pre-1970 } & \multicolumn{2}{|l|}{ Post- 1970} \\
\hline & 1st & 2nd & $\overline{1 \mathrm{st}}$ & 2nd & $\overline{1 \text { 1st }}$ & 2nd \\
\hline & $0.513^{* * *}$ & $0.389 * * *$ & $0.528^{* * *}$ & $0.376^{* * *}$ & $0.342^{* * *}$ & $0.555^{* * *}$ \\
\hline & $(0.001)$ & $(0.003)$ & $(0.001)$ & $(0.005)$ & $(0.004)$ & $(0.007)$ \\
\hline $\mathrm{SE}$ & $0.091^{* * *}$ & $0.176^{* * *}$ & $0.105^{* * *}$ & $-0.010^{* * *}$ & $0.167^{* * *}$ & $0.179^{* * *}$ \\
\hline & $(0.001)$ & $(0.002)$ & $(0.001)$ & $(0.003)$ & $(0.002)$ & $(0.004)$ \\
\hline $\mathrm{EE}$ & $0.049 * * *$ & $0.096^{* * *}$ & $0.066^{* * *}$ & $-0.005^{* *}$ & $0.078^{* * *}$ & $0.095^{* * *}$ \\
\hline & $(0.001)$ & $(0.008)$ & $(0.001)$ & $(0.002)$ & $(0.011)$ & $(0.011)$ \\
\hline $\mathrm{AF}$ & $0.487^{* * *}$ & $0.186^{* * *}$ & $0.514^{* * *}$ & $0.388^{* * *}$ & $0.125^{* * *}$ & $0.302^{* * *}$ \\
\hline & $(0.006)$ & $(0.036)$ & $(0.006)$ & $(0.012)$ & $(0.040)$ & $(0.068)$ \\
\hline TMM & $0.060^{* * *}$ & $-0.023^{* * *}$ & $0.094^{* * *}$ & $-0.028^{* * *}$ & -0.017 & $-0.039 * * *$ \\
\hline & $(0.002)$ & $(0.007)$ & $(0.003)$ & $(0.004)$ & $(0.011)$ & $(0.009)$ \\
\hline LA & $0.646^{* * *}$ & $0.423^{* * *}$ & $0.649 * * *$ & $0.622^{* * *}$ & $0.389^{* * *}$ & $0.521^{* * *}$ \\
\hline & $(0.003)$ & $(0.029)$ & $(0.003)$ & $(0.007)$ & $(0.033)$ & $(0.059)$ \\
\hline AS & $0.589^{* * *}$ & $0.574^{* * *}$ & $0.592^{* * *}$ & $0.560 * * *$ & $0.589^{* * *}$ & $0.507 * * *$ \\
\hline & $(0.003)$ & $(0.035)$ & $(0.003)$ & $(0.008)$ & $(0.040)$ & $(0.074)$ \\
\hline $\mathrm{SCA}$ & -0.002 & $-0.061^{* * *}$ & $0.023^{* * *}$ & $-0.062^{* * *}$ & $-0.066^{* * *}$ & -0.052 \\
\hline & $(0.004)$ & $(0.016)$ & $(0.005)$ & $(0.005)$ & $(0.018)$ & $(0.035)$ \\
\hline Education & $0.007^{* * *}$ & & $0.007 * * *$ & & & \\
\hline & $(0.001)$ & & $(0.001)$ & & & \\
\hline Observations & 1492037 & & 1492037 & & & \\
\hline PR2 & 0.18 & & 0.18 & & & \\
\hline 11 & -548027 & & -546437 & & & \\
\hline
\end{tabular}

Table 10: Early marriage vs. cohabitation

\begin{tabular}{|c|c|c|c|c|c|c|c|c|}
\hline \multicolumn{3}{|c|}{ Early marriage } & \multicolumn{6}{|c|}{ Cohabitation } \\
\hline & All & & All & & Pre-1970 & & Post-1970 & \\
\hline Origin & 1 1st & 2nd & $\overline{1 \text { 1st }}$ & 2nd & 1st & $\overline{2 \text { 2nd }}$ & $\overline{1 \text { 1st }}$ & 2nd \\
\hline WE & $\begin{array}{l}0.124^{* * *} \\
(0.004)\end{array}$ & $\begin{array}{l}-0.0170^{* * *} \\
(0.002)\end{array}$ & $\begin{array}{l}-0.0240^{* * *} \\
(0.001)\end{array}$ & $\begin{array}{l}0.00376^{* *} \\
(0.001)\end{array}$ & $\begin{array}{l}-0.0200^{* * *} \\
(0.0007)\end{array}$ & $\begin{array}{l}-0.0125^{* * *} \\
(0.002)\end{array}$ & $\begin{array}{l}-0.0403^{* * *} \\
(0.001)\end{array}$ & $\begin{array}{l}0.0375^{* * *} \\
(0.004)\end{array}$ \\
\hline $\mathrm{SE}$ & $\begin{array}{l}0.291^{* * *} \\
(0.005)\end{array}$ & $\begin{array}{l}0.046^{* * *} \\
(0.002)\end{array}$ & $\begin{array}{l}-0.060^{* * *} \\
(0.001)\end{array}$ & $\begin{array}{l}-0.034^{* * *} \\
(0.001)\end{array}$ & $\begin{array}{l}-0.054^{* * *} \\
(0.001)\end{array}$ & $\begin{array}{l}-0.041^{* * *} \\
(0.001)\end{array}$ & $\begin{array}{l}-0.072^{* * *} \\
(0.001)\end{array}$ & $\begin{array}{l}-0.030^{* * *} \\
(0.001)\end{array}$ \\
\hline $\mathrm{EE}$ & $\begin{array}{l}0.522^{* * *} \\
(0.004)\end{array}$ & $\begin{array}{l}0.191^{* * *} \\
(0.009)\end{array}$ & $\begin{array}{l}-0.079^{* * *} \\
(0.0003)\end{array}$ & $\begin{array}{l}-0.055^{* * *} \\
(0.001)\end{array}$ & $\begin{array}{l}-0.065^{* * *} \\
(0.001)\end{array}$ & $\begin{array}{l}-0.054^{* * *} \\
(0.003)\end{array}$ & $\begin{array}{l}-0.083^{* * *} \\
(0.0002)\end{array}$ & $\begin{array}{l}-0.059^{* * *} \\
(0.002)\end{array}$ \\
\hline $\mathrm{AF}$ & $\begin{array}{l}0.273^{* * *} \\
(0.011)\end{array}$ & $\begin{array}{l}0.123^{* * *} \\
(0.039)\end{array}$ & $\begin{array}{l}-0.060^{* * *} \\
(0.001)\end{array}$ & $\begin{array}{l}-0.063^{* * *} \\
(0.006)\end{array}$ & $\begin{array}{l}-0.052^{* * * *} \\
(0.002)\end{array}$ & $\begin{array}{l}-0.075^{* * * *} \\
(0.005)\end{array}$ & $\begin{array}{l}-0.071^{* * * *} \\
(0.001)\end{array}$ & $\begin{array}{l}-0.052^{* * *} \\
(0.012)\end{array}$ \\
\hline TMM & $\begin{array}{l}0.532^{* * *} \\
(0.007)\end{array}$ & $\begin{array}{l}0.232^{* * *} \\
(0.011)\end{array}$ & $\begin{array}{l}-0.077^{* * *} \\
(0.0003)\end{array}$ & $\begin{array}{l}-0.072^{* * *} \\
(0.001)\end{array}$ & $\begin{array}{l}-0.069^{* * *} \\
(0.0007)\end{array}$ & $\begin{array}{l}-0.064^{* * * *} \\
(0.003)\end{array}$ & $\begin{array}{l}-0.082^{* * *} \\
(0.0002)\end{array}$ & $\begin{array}{l}-0.076^{* * *} \\
(0.001)\end{array}$ \\
\hline LA & $\begin{array}{l}0.403^{* * *} \\
(0.009)\end{array}$ & $\begin{array}{l}0.064^{* * *} \\
(0.024)\end{array}$ & $\begin{array}{l}-0.066^{* * *} \\
(0.0006)\end{array}$ & $\begin{array}{l}-0.045^{* * *} \\
(0.007)\end{array}$ & $\begin{array}{l}-0.058^{* * *} \\
(0.001)\end{array}$ & $\begin{array}{l}-0.044^{* * *} \\
(0.010)\end{array}$ & $\begin{array}{l}-0.075^{* * *} \\
(0.0006)\end{array}$ & $\begin{array}{l}-0.052^{* * *} \\
(0.010)\end{array}$ \\
\hline AS & $\begin{array}{l}0.250^{* * *} \\
(0.009)\end{array}$ & $\begin{array}{l}-0.020 \\
(0.023)\end{array}$ & $\begin{array}{l}-0.062^{* * *} \\
(0.0007)\end{array}$ & $\begin{array}{l}-0.049^{* * *} \\
(0.009)\end{array}$ & $\begin{array}{l}-0.055^{* * *} \\
(0.001)\end{array}$ & $\begin{array}{l}-0.072^{* * *} \\
(0.006)\end{array}$ & $\begin{array}{l}-0.074^{* * *} \\
(0.0007)\end{array}$ & $\begin{array}{l}-0.011 \\
(0.024)\end{array}$ \\
\hline SCA & $\begin{array}{l}0.432^{* * *} \\
(0.012)\end{array}$ & $\begin{array}{l}0.313^{* * *} \\
(0.057)\end{array}$ & $\begin{array}{l}-0.077 * * * \\
(0.0004)\end{array}$ & $\begin{array}{l}-0.075^{* * *} \\
(0.002)\end{array}$ & $\begin{array}{l}-0.074 * * * \\
(0.0008)\end{array}$ & $\begin{array}{l}-0.077^{* * *} \\
(0.003)\end{array}$ & $\begin{array}{l}-0.079 * * * \\
(0.0004)\end{array}$ & $\begin{array}{l}-0.076^{* * *} \\
(0.003)\end{array}$ \\
\hline Education & $\begin{array}{l}-0.018^{* * *} \\
(0.0002)\end{array}$ & & $\begin{array}{l}0.002 * * * \\
(9.92 \mathrm{e}-05)\end{array}$ & & $\begin{array}{l}0.002^{* * *} \\
(9.97 \mathrm{e}-05)\end{array}$ & & & \\
\hline Observations & 281477 & & 1531937 & & 1531937 & & & \\
\hline PR2 & 0.30 & & 0.13 & & 0.13 & & & \\
\hline ll & -79229 & & -454518 & & -452617 & & & \\
\hline
\end{tabular}


Table 11: Age gap between partners

\begin{tabular}{|c|c|c|c|c|c|c|}
\hline & All & & Endo & & Inter & \\
\hline Origin & 1st & 2nd & 1st & 2nd & 1st & 2nd \\
\hline \multirow[t]{2}{*}{ WE } & $-0.070^{* * *}$ & $0.101^{* * *}$ & $-0.152^{* * *}$ & $-0.123^{* *}$ & $-0.073^{* * *}$ & $0.254^{* * *}$ \\
\hline & $(0.015)$ & $(0.038)$ & $(0.024)$ & $(0.055)$ & $(0.020)$ & $(0.057)$ \\
\hline \multirow[t]{2}{*}{$\mathrm{SE}$} & $0.118^{* * *}$ & $0.444^{* * *}$ & $-0.060^{* * *}$ & $0.238^{* * *}$ & $0.695^{* * *}$ & $0.740^{* * *}$ \\
\hline & $(0.017)$ & $(0.026)$ & $(0.019)$ & $(0.031)$ & $(0.039)$ & $(0.049)$ \\
\hline \multirow[t]{2}{*}{$\mathrm{EE}$} & $-0.424^{* * *}$ & $0.301^{* * *}$ & -0.026 & $0.321^{* * *}$ & $-2.102^{* * *}$ & 0.235 \\
\hline & $(0.018)$ & $(0.092)$ & $(0.020)$ & $(0.108)$ & $(0.048)$ & $(0.221)$ \\
\hline \multirow[t]{2}{*}{$\mathrm{AF}$} & $-2.645^{* * *}$ & -0.174 & $-2.280^{* * *}$ & $1.465^{* * *}$ & $-3.648^{* * *}$ & $-3.991^{* * *}$ \\
\hline & $(0.058)$ & $(0.366)$ & $(0.100)$ & $(0.471)$ & $(0.086)$ & $(0.729)$ \\
\hline \multirow[t]{2}{*}{ TMM } & $-1.174^{* * *}$ & 0.099 & $-0.797^{* * *}$ & $0.335^{* * *}$ & $-2.618^{* * *}$ & $-1.410^{* * *}$ \\
\hline & $(0.034)$ & $(0.116)$ & $(0.039)$ & $(0.126)$ & $(0.090)$ & $(0.396)$ \\
\hline \multirow[t]{2}{*}{ LA } & $-1.334^{* * *}$ & $-0.676^{* *}$ & -0.115 & -0.380 & $-1.734^{* * *}$ & $-0.892^{* *}$ \\
\hline & $(0.039)$ & $(0.275)$ & $(0.087)$ & $(0.440)$ & $(0.050)$ & $(0.432)$ \\
\hline \multirow[t]{2}{*}{ AS } & $-1.799^{* * *}$ & $-1.547 * * *$ & $-0.704^{* * *}$ & -0.223 & $-2.457^{* * *}$ & $-1.866^{* * *}$ \\
\hline & $(0.039)$ & $(0.380)$ & $(0.072)$ & $(0.695)$ & $(0.051)$ & $(0.510)$ \\
\hline \multirow[t]{2}{*}{$\mathrm{SCA}$} & $-1.559^{* * *}$ & $-1.485^{* * *}$ & $-1.597^{* * *}$ & $-1.662^{* * *}$ & $-1.359^{* * *}$ & 1.578 \\
\hline & $(0.055)$ & $(0.299)$ & $(0.060)$ & $(0.312)$ & $(0.175)$ & $(1.262)$ \\
\hline \multirow[t]{2}{*}{ Education } & $0.072^{* * *}$ & & $0.077^{* * *}$ & & & \\
\hline & $(0.001)$ & & $(0.001)$ & & & \\
\hline Observations & 1532692 & & 1532692 & & & \\
\hline $\mathrm{R} 2$ & 0.03 & & 0.03 & & & \\
\hline
\end{tabular}

Table 12: Education gap between partners

\begin{tabular}{|c|c|c|c|c|c|c|c|c|}
\hline & Pre-1970 & & Post-1970 & & Endo & & Inter & \\
\hline Origin & 1 1st & 2nd & 1 1st & 2nd & 1 1st & 2nd & 1 1st & 2nd \\
\hline \multirow[t]{2}{*}{ WE } & $-0.213^{* * *}$ & $-0.260^{* * *}$ & $0.100^{* * *}$ & $0.062^{*}$ & $-0.728^{* * *}$ & $-0.381^{* * *}$ & -0.014 & $-0.214^{* * *}$ \\
\hline & $(0.007)$ & $(0.019)$ & $(0.023)$ & $(0.035)$ & $(0.011)$ & $(0.024)$ & $(0.009)$ & $(0.025)$ \\
\hline \multirow[t]{2}{*}{ SE } & $1.481^{* * *}$ & $0.870^{* * *}$ & $1.421^{* * *}$ & $0.889 * * *$ & $1.941 * * *$ & $1.285^{* * *}$ & $-0.241^{* * *}$ & $-0.115^{* * *}$ \\
\hline & $(0.008)$ & $(0.013)$ & $(0.021)$ & $(0.021)$ & $(0.008)$ & $(0.014)$ & $(0.017)$ & $(0.022)$ \\
\hline \multirow[t]{2}{*}{$\mathrm{EE}$} & $0.960^{* * *}$ & $1.079^{* * *}$ & $1.030^{* * *}$ & $0.888^{* * *}$ & $1.133^{* * *}$ & $1.312^{* * *}$ & $0.351^{* * *}$ & -0.035 \\
\hline & $(0.009)$ & $(0.057)$ & $(0.016)$ & $(0.059)$ & (0.009) & $(0.047)$ & $(0.021)$ & (0.098) \\
\hline \multirow[t]{2}{*}{$\mathrm{AF}$} & $-0.076^{* *}$ & -0.027 & $-0.105^{* *}$ & $1.138^{* * *}$ & $0.223^{* * *} *$ & $0.514^{* *}$ & $-0.518^{* * *}$ & 0.020 \\
\hline & $(0.030)$ & $(0.196)$ & $(0.050)$ & $(0.295)$ & $(0.044)$ & $(0.209)$ & $(0.038)$ & $(0.323)$ \\
\hline \multirow[t]{2}{*}{ TMM } & $1.066^{* * *}$ & $0.938 * * *$ & $1.042^{* * *}$ & $1.166^{* * *}$ & $1.405^{* * *}$ & $1.220^{* * *}$ & $-0.153^{* * *}$ & -0.167 \\
\hline & $(0.018)$ & $(0.073)$ & $(0.029)$ & $(0.072)$ & $(0.017)$ & $(0.056)$ & $(0.040)$ & $(0.175)$ \\
\hline \multirow[t]{2}{*}{ LA } & $0.077^{* * *}$ & -0.054 & $-0.293^{* * *}$ & -0.007 & $0.355^{* * *}$ & -0.086 & $-0.331^{* * *}$ & -0.225 \\
\hline & $(0.020)$ & $(0.142)$ & $(0.034)$ & $(0.246)$ & $(0.038)$ & $(0.195)$ & $(0.022)$ & $(0.191)$ \\
\hline \multirow[t]{2}{*}{ AS } & $0.034 *$ & $0.443^{* *}$ & $-0.307^{* * *}$ & 0.025 & $0.669^{* * *}$ & $1.070^{* * *}$ & $-0.325^{* * *}$ & 0.084 \\
\hline & $(0.019)$ & $(0.199)$ & (0.038) & $(0.325)$ & $(0.032)$ & $(0.308)$ & $(0.022)$ & $(0.226)$ \\
\hline \multirow[t]{2}{*}{$\mathrm{SCA}$} & $0.968^{* * *}$ & -0.005 & $1.572^{* * *}$ & $1.135^{* * *}$ & $1.467^{* * *}$ & $0.301^{* *}$ & $-0.339^{* * *}$ & -0.195 \\
\hline & $(0.030)$ & $(0.150)$ & $(0.043)$ & $(0.291)$ & $(0.026)$ & $(0.138)$ & $(0.077)$ & $(0.559)$ \\
\hline \multirow[t]{2}{*}{ Education } & $0.425^{* * *}$ & & & & $0.444^{* * *}$ & & & \\
\hline & $(0.0008)$ & & & & $(0.0008)$ & & & \\
\hline Observations & 1532692 & & & & 1532692 & & & \\
\hline $\mathrm{R} 2$ & 0.17 & & & & 0.18 & & & \\
\hline
\end{tabular}


Table 13: Completed fertility rate

\begin{tabular}{|c|c|c|c|c|c|c|}
\hline & All & & Endo & & Inter & \\
\hline Origin & 1 1st & 2nd & 1st & 2nd & 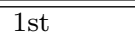 & $\overline{2 \text { 2nd }}$ \\
\hline WE & $\begin{array}{l}-0.122^{* * *} \\
(0.003)\end{array}$ & $\begin{array}{l}-0.056^{* * *} \\
(0.011)\end{array}$ & $\begin{array}{l}-0.180^{* * *} \\
(0.007)\end{array}$ & $\begin{array}{l}-0.074^{* * *} \\
(0.016)\end{array}$ & $\begin{array}{l}-0.195^{* * *} \\
(0.005)\end{array}$ & $\begin{array}{c}-0.047^{*} \\
(0.025)\end{array}$ \\
\hline SE & $\begin{array}{l}0.076 * * * \\
(0.004)\end{array}$ & $\begin{array}{l}0.061 * * * \\
(0.010)\end{array}$ & $\begin{array}{l}0.012^{* *} \\
(0.005)\end{array}$ & $\begin{array}{l}-0.026^{* *} \\
(0.012)\end{array}$ & $\begin{array}{l}-0.189 * * * \\
(0.011)\end{array}$ & $\begin{array}{l}-0.070^{* *} \\
(0.027)\end{array}$ \\
\hline $\mathrm{EE}$ & $\begin{array}{l}0.200^{* * *} \\
(0.006)\end{array}$ & $\begin{array}{l}0.226^{* * *} \\
(0.042)\end{array}$ & $\begin{array}{l}0.273^{* * *} \\
(0.007)\end{array}$ & $\begin{array}{l}0.189^{* * *} \\
(0.046)\end{array}$ & $\begin{array}{l}-0.443^{* * *} \\
(0.016)\end{array}$ & $\begin{array}{l}-0.202 \\
(0.137)\end{array}$ \\
\hline $\mathrm{AF}$ & $\begin{array}{l}0.396^{* * *} \\
(0.020)\end{array}$ & $\begin{array}{l}0.325^{* * *} \\
(0.126)\end{array}$ & $\begin{array}{l}0.862^{* * *} \\
(0.042)\end{array}$ & $\begin{array}{l}0.219 \\
(0.173)\end{array}$ & $\begin{array}{l}-0.093^{* * *} \\
(0.031)\end{array}$ & $\begin{array}{l}-0.354 \\
(0.356)\end{array}$ \\
\hline TMM & $\begin{array}{l}0.560 * * * \\
(0.012)\end{array}$ & $\begin{array}{l}0.339 * * * \\
(0.054)\end{array}$ & $\begin{array}{l}0.702^{* * *} \\
(0.015)\end{array}$ & $\begin{array}{l}0.242^{* * *} \\
(0.061)\end{array}$ & $\begin{array}{l}-0.173^{* * *} \\
(0.031)\end{array}$ & $\begin{array}{l}-0.077 \\
(0.252)\end{array}$ \\
\hline LA & $\begin{array}{l}0.167^{* * *} \\
(0.013)\end{array}$ & $\begin{array}{l}0.088 \\
(0.085)\end{array}$ & $\begin{array}{l}0.271^{* * *} \\
(0.032)\end{array}$ & $\begin{array}{l}0.038 \\
(0.136)\end{array}$ & $\begin{array}{l}-0.200^{* * *} \\
(0.019)\end{array}$ & $\begin{array}{l}-0.091 \\
(0.175)\end{array}$ \\
\hline AS & $\begin{array}{l}0.031^{* *} \\
(0.013)\end{array}$ & $\begin{array}{l}-0.183 \\
(0.154)\end{array}$ & $\begin{array}{l}0.375^{* * *} \\
(0.025)\end{array}$ & $\begin{array}{l}0.022 \\
(0.283)\end{array}$ & $\begin{array}{l}-0.417^{* * *} \\
(0.019)\end{array}$ & $\begin{array}{c}-0.432^{*} \\
(0.225)\end{array}$ \\
\hline SCA & $\begin{array}{l}0.410^{* * *} \\
(0.022)\end{array}$ & $\begin{array}{l}0.300^{* * *} \\
(0.102)\end{array}$ & $\begin{array}{l}0.351^{* * *} \\
(0.028)\end{array}$ & $\begin{array}{l}0.026 \\
(0.109)\end{array}$ & $\begin{array}{l}-0.193^{* * *} \\
(0.060)\end{array}$ & $\begin{array}{l}0.372 \\
(0.552)\end{array}$ \\
\hline Education & $\begin{array}{l}-0.058^{* * *} \\
(0.0004)\end{array}$ & & $\begin{array}{l}-0.041^{* * *} \\
(0.0004) \\
\end{array}$ & & & \\
\hline Observations & 1512842 & & 1512842 & & & \\
\hline $\mathrm{R} 2$ & 0.08 & & 0.23 & & & \\
\hline
\end{tabular}


Table 14: Group averages: female labour force participation (in \%)

\begin{tabular}{lllllllllll} 
& Natives & WE & SE & EE & AF & TMM & SA & AS & SCA & Total \\
\hline \hline Born in Switzerland & 75.4 & 81.9 & 84.1 & 82.1 & 82.6 & 82.9 & 78.3 & 71.4 & 77.5 & 76 \\
Married & 67 & 73.3 & 76.7 & 76.5 & 78.5 & 77.3 & 70.4 & 66 & 76.9 & 67.6 \\
Single & 88.7 & 90.6 & 93.3 & 90.9 & 89.1 & 90.8 & 88.2 & 78.7 & 81.3 & 89 \\
\hline Foreign born & & 72.1 & 74.6 & 74.8 & 75.1 & 69.3 & 70.6 & 68.8 & 70.3 & 73 \\
Married & & 65.2 & 72.4 & 73 & 73.4 & 67.3 & 67.4 & 64.6 & 68.8 & 69.6 \\
Single & 86.1 & 83.2 & 83.2 & 78.8 & 78.1 & 82.1 & 83.2 & 77.5 & 83.8 \\
\hline \hline
\end{tabular}

Source: Swiss census, 2000

Table 15: Female labour force participation

\begin{tabular}{|c|c|c|c|c|c|c|c|c|}
\hline & Pre-1970 & & Post-1970 & & Endo & & Inter & \\
\hline Origin & $1 \mathrm{st}$ & 2nd & $1 \mathrm{st}$ & 2nd & $1 \mathrm{st}$ & 2nd & $1 \mathrm{st}$ & 2nd \\
\hline WE & $\begin{array}{l}-0.041^{* * *} \\
(0.001)\end{array}$ & $\begin{array}{l}0.010^{* * *} \\
(0.003)\end{array}$ & $\begin{array}{l}-0.009^{* * *} \\
(0.003)\end{array}$ & $\begin{array}{l}0.040^{* * *} \\
(0.004)\end{array}$ & $\begin{array}{l}-0.086^{* * *} \\
(0.002)\end{array}$ & $\begin{array}{l}0.029^{* * *} \\
(0.004)\end{array}$ & $\begin{array}{l}-0.020^{* * *} \\
(0.001)\end{array}$ & $\begin{array}{l}-0.015^{* * *} \\
(0.005)\end{array}$ \\
\hline SE & $\begin{array}{l}0.039^{* * *} \\
(0.001)\end{array}$ & $\begin{array}{l}0.019 * * * \\
(0.002)\end{array}$ & $\begin{array}{l}0.068^{* * *} \\
(0.003)\end{array}$ & $\begin{array}{l}0.086^{* * * *} \\
(0.002)\end{array}$ & $\begin{array}{l}0.092^{* * * *} \\
(0.001)\end{array}$ & $\begin{array}{l}0.064^{* * * *} \\
(0.002)\end{array}$ & $\begin{array}{l}-0.008^{* *} \\
(0.003)\end{array}$ & $\begin{array}{l}0.001 \\
(0.004)\end{array}$ \\
\hline $\mathrm{EE}$ & $\begin{array}{l}-0.007^{* * * *} \\
(0.001)\end{array}$ & $\begin{array}{l}0.008 \\
(0.009)\end{array}$ & $\begin{array}{l}-0.043^{* * * *} \\
(0.002)\end{array}$ & $\begin{array}{l}0.057^{* * *} \\
(0.008)\end{array}$ & $\begin{array}{l}0.048^{* * *} \\
(0.001)\end{array}$ & $\begin{array}{l}0.088^{* * *} \\
(0.006)\end{array}$ & $\begin{array}{l}-0.013^{* * *} \\
(0.004)\end{array}$ & $\begin{array}{l}0.003 \\
(0.019)\end{array}$ \\
\hline $\mathrm{AF}$ & $\begin{array}{l}-0.009^{* *} \\
(0.004)\end{array}$ & $\begin{array}{l}0.036 \\
(0.028)\end{array}$ & $\begin{array}{l}-0.055^{* * *} \\
(0.008)\end{array}$ & $\begin{array}{l}-0.031 \\
(0.043)\end{array}$ & $\begin{array}{l}0.048^{* * *} \\
(0.006)\end{array}$ & $\begin{array}{l}0.080^{* * *} \\
(0.029)\end{array}$ & $\begin{array}{c}-0.013^{*} \\
(0.006)\end{array}$ & $\begin{array}{l}-0.138^{*} \\
(0.071)\end{array}$ \\
\hline TMM & $\begin{array}{l}-0.078^{* * * *} \\
(0.003)\end{array}$ & $\begin{array}{l}-0.003 \\
(0.012)\end{array}$ & $\begin{array}{l}-0.075^{* * * *} \\
(0.005)\end{array}$ & $\begin{array}{l}0.030 * * * \\
(0.010)\end{array}$ & $\begin{array}{l}-0.001 \\
(0.002)\end{array}$ & $\begin{array}{l}0.062 * * * \\
(0.008)\end{array}$ & $\begin{array}{l}-0.030 * * * \\
(0.007)\end{array}$ & $\begin{array}{l}0.046 \\
(0.031)\end{array}$ \\
\hline LA & $\begin{array}{l}-0.088^{* * *} \\
(0.003)\end{array}$ & $\begin{array}{l}-0.006 \\
(0.022)\end{array}$ & $\begin{array}{l}-0.143^{* * *} \\
(0.006)\end{array}$ & $\begin{array}{l}-0.026 \\
(0.032)\end{array}$ & $\begin{array}{l}0.004 \\
(0.006)\end{array}$ & $\begin{array}{l}0.012 \\
(0.034)\end{array}$ & $\begin{array}{l}-0.095^{* * *} \\
(0.004)\end{array}$ & $\begin{array}{l}-0.040 \\
(0.036)\end{array}$ \\
\hline AS & $\begin{array}{l}-0.095^{* * *} \\
(0.003)\end{array}$ & $\begin{array}{l}-0.127^{* * *} \\
(0.036)\end{array}$ & $\begin{array}{l}-0.187^{* * *} \\
(0.007)\end{array}$ & $\begin{array}{l}-0.124^{* *} \\
(0.048)\end{array}$ & $\begin{array}{l}-0.011^{* *} \\
(0.005)\end{array}$ & $\begin{array}{l}0.006 \\
(0.053)\end{array}$ & $\begin{array}{l}-0.107^{* * *} \\
(0.004)\end{array}$ & $\begin{array}{l}-0.108^{* *} \\
(0.046)\end{array}$ \\
\hline $\mathrm{SCA}$ & $\begin{array}{l}-0.076^{* * *} \\
(0.005)\end{array}$ & $\begin{array}{l}-0.011 \\
(0.025)\end{array}$ & $\begin{array}{l}-0.151^{* * *} \\
(0.008)\end{array}$ & $\begin{array}{l}-0.008 \\
(0.052)\end{array}$ & $\begin{array}{l}-0.011^{* *} \\
(0.004)\end{array}$ & $\begin{array}{l}0.043^{* *} \\
(0.021)\end{array}$ & $\begin{array}{l}-0.091 * * * \\
(0.016)\end{array}$ & $\begin{array}{l}-0.033 \\
(0.112)\end{array}$ \\
\hline Education & $\begin{array}{l}0.017 * * * \\
(0.0001)\end{array}$ & & & & $\begin{array}{l}0.017^{* * *} \\
(0.0001)\end{array}$ & & & \\
\hline Observations & 1795117 & & & & 1795117 & & & \\
\hline PR2 & 0.05 & & & & 0.09 & & & \\
\hline 11 & -934436 & & & & -888678 & & & \\
\hline
\end{tabular}




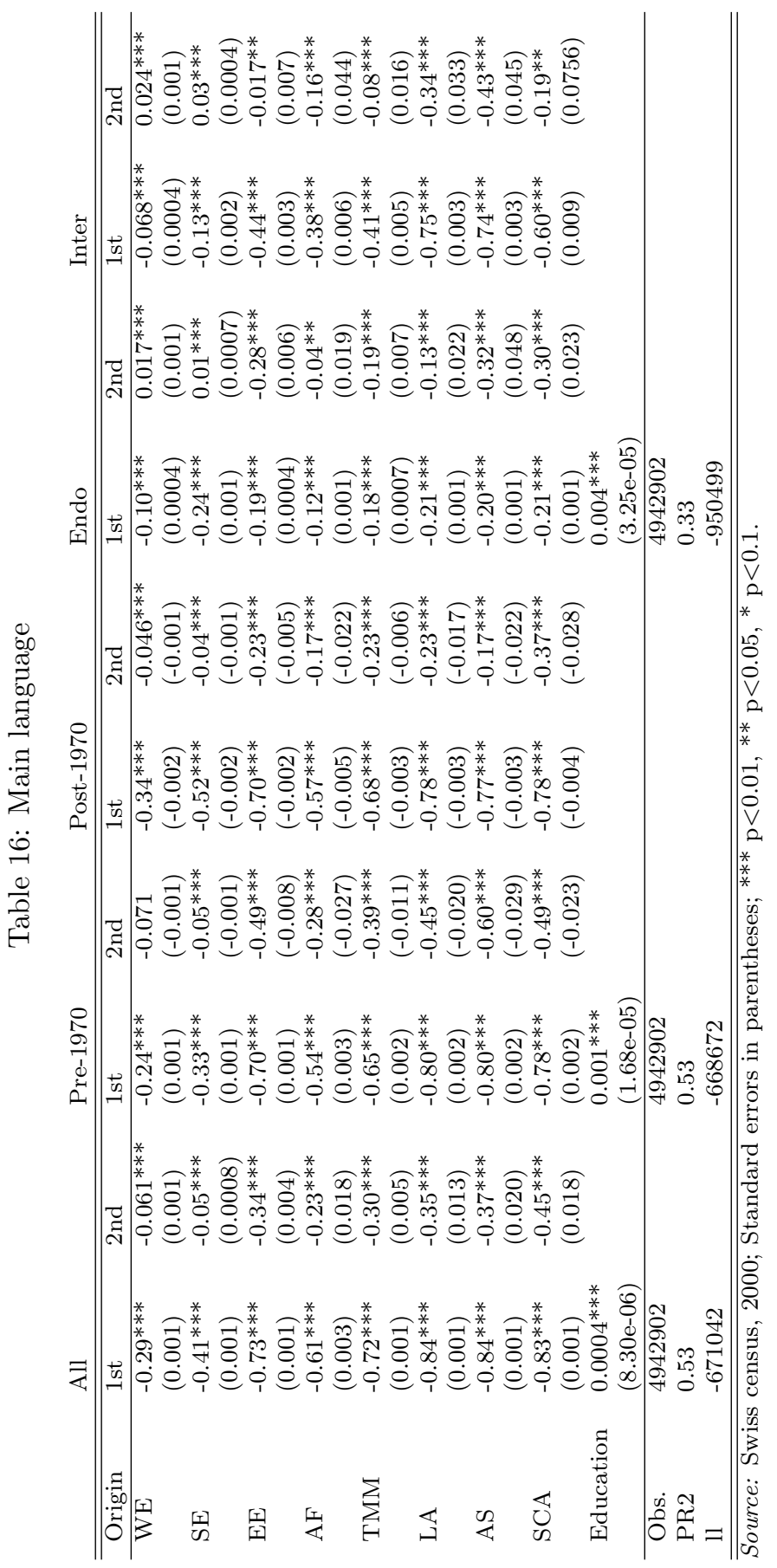


Table 17: In favor of more equality between Swiss and foreigners

\begin{tabular}{lllllll} 
& All & \multicolumn{3}{c}{ Pre-1970 } & Post-1970 \\
\hline \hline Origin & 1st & 2nd & 1st & 2nd & 1st & 2nd \\
\hline WE & $0.153^{* * *}$ & $0.055^{* * *}$ & $0.155^{* * *}$ & $0.036^{* * *}$ & $0.136^{* * *}$ & $0.086^{* * *}$ \\
& $(0.008)$ & $(0.010)$ & $(0.009)$ & $(0.013)$ & $(0.022)$ & $(0.016)$ \\
SE & $0.207^{* * *}$ & $0.103^{* * *}$ & $0.206^{* * *}$ & $0.103^{* * *}$ & $0.199^{* * *}$ & $0.102^{* * *}$ \\
& $(0.008)$ & $(0.010)$ & $(0.009)$ & $(0.012)$ & $(0.021)$ & $(0.015)$ \\
EE & $0.104^{* * *}$ & $0.087^{* * *}$ & $0.088^{* * *}$ & 0.014 & $0.133^{* * *}$ & $0.165^{* * *}$ \\
& $(0.019)$ & $(0.029)$ & $(0.024)$ & $(0.044)$ & $(0.030)$ & $(0.037)$ \\
AF & 0.023 & 0.069 & -0.075 & 0.052 & $0.221^{* * *}$ & 0.107 \\
& $(0.053)$ & $(0.086)$ & $(0.068)$ & $(0.104)$ & $(0.065)$ & $(0.153)$ \\
TMM & 0.005 & $0.137^{* * *}$ & -0.023 & $0.099^{* *}$ & 0.060 & $0.174^{* * *}$ \\
& $(0.037)$ & $(0.030)$ & $(0.047)$ & $(0.045)$ & $(0.060)$ & $(0.039)$ \\
LA & $0.186^{* * *}$ & 0.031 & $0.193^{* * *}$ & 0.036 & $0.171^{* * *}$ & 0.022 \\
& $(0.027)$ & $(0.054)$ & $(0.032)$ & $(0.068)$ & $(0.047)$ & $(0.091)$ \\
AS & 0.050 & $-0.212^{*}$ & 0.011 & $-0.217^{*}$ & 0.130 & -0.202 \\
& $(0.062)$ & $(0.111)$ & $(0.079)$ & $(0.128)$ & $(0.099)$ & $(0.225)$ \\
SCA & 0.027 & 0.104 & 0.044 & 0.065 & -0.003 & 0.182 \\
& $(0.057)$ & $(0.076)$ & $(0.070)$ & $(0.097)$ & $(0.099)$ & $(0.115)$ \\
Education & $0.026^{* * *}$ & & $0.026^{* * *}$ & & & \\
& $(0.001)$ & & $(0.001)$ & & & \\
\hline Observations & 40692 & & 40692 & & & \\
PR2 & 0.038 & & 0.039 & & & \\
ll & -25581 & & -25568 & & & \\
\hline
\end{tabular}

Source: SHP, 1999-2007; Standard errors in parentheses; ${ }^{* * *} \mathrm{p}<0.01,{ }^{* *} \mathrm{p}<0.05,{ }^{*} \mathrm{p}<0.1$.

Table 18: In favor of opening Swiss traditions

\begin{tabular}{|c|c|c|c|c|c|c|}
\hline & All & & Pre-1970 & & Post-1970 & \\
\hline Origin & 1st & 2nd & 1st & 2nd & 1st & 2nd \\
\hline$\overline{\mathrm{WE}}$ & $\begin{array}{l}0.137^{* * *} \\
(0.009)\end{array}$ & $\begin{array}{l}0.063^{* * *} \\
(0.010)\end{array}$ & $\begin{array}{l}0.266^{* * *} \\
(0.045)\end{array}$ & $\begin{array}{l}0.032 \\
(0.056)\end{array}$ & $\begin{array}{l}-0.350 * * * \\
(0.103)\end{array}$ & $\begin{array}{c}-0.125^{*} \\
(0.071)\end{array}$ \\
\hline $\mathrm{SE}$ & $\begin{array}{l}0.170^{* * *} \\
(0.009)\end{array}$ & $\begin{array}{l}0.096^{* * *} \\
(0.010)\end{array}$ & $\begin{array}{l}0.073 \\
(0.053)\end{array}$ & $\begin{array}{c}-0.043 \\
(0.056)\end{array}$ & $\begin{array}{l}-0.665^{* * * *} \\
(0.117)\end{array}$ & $\begin{array}{l}-0.214^{* * *} \\
(0.069)\end{array}$ \\
\hline $\mathrm{EE}$ & $\begin{array}{l}0.067^{* * *} \\
(0.020)\end{array}$ & $\begin{array}{l}0.109 * * * \\
(0.028)\end{array}$ & $\begin{array}{l}0.964^{* * *} \\
(0.107)\end{array}$ & $\begin{array}{l}0.095 \\
(0.177)\end{array}$ & $\begin{array}{l}0.975^{* * *} \\
(0.144)\end{array}$ & $\begin{array}{l}0.473^{* * *} \\
(0.183)\end{array}$ \\
\hline $\mathrm{AF}$ & $\begin{array}{l}-0.011 \\
(0.053)\end{array}$ & $\begin{array}{l}-0.043 \\
(0.093)\end{array}$ & $\begin{array}{l}0.953^{* * *} \\
(0.258)\end{array}$ & $\begin{array}{l}0.246 \\
(0.438)\end{array}$ & $\begin{array}{l}0.343 \\
(0.343)\end{array}$ & $\begin{array}{l}1.330^{* *} \\
(0.636)\end{array}$ \\
\hline TMM & $\begin{array}{l}0.037 \\
(0.036)\end{array}$ & $\begin{array}{l}0.131^{* * *} \\
(0.030)\end{array}$ & $\begin{array}{l}1.188^{* * *} \\
(0.188)\end{array}$ & $\begin{array}{l}-0.057 \\
(0.201)\end{array}$ & $\begin{array}{l}0.516^{* *} \\
(0.249)\end{array}$ & $\begin{array}{l}0.519 * * * \\
(0.195)\end{array}$ \\
\hline LA & $\begin{array}{l}0.155^{* * *} \\
(0.028)\end{array}$ & $\begin{array}{l}-0.0002 \\
(0.055)\end{array}$ & $\begin{array}{l}0.309^{*} \\
(0.171)\end{array}$ & $\begin{array}{l}0.549^{* *} \\
(0.276)\end{array}$ & $\begin{array}{l}-0.559^{* *} \\
(0.249)\end{array}$ & $\begin{array}{l}0.041 \\
(0.390)\end{array}$ \\
\hline AS & $\begin{array}{l}0.033 \\
(0.063)\end{array}$ & $\begin{array}{l}-0.101 \\
(0.109)\end{array}$ & $\begin{array}{l}0.656^{* *} \\
(0.323)\end{array}$ & $\begin{array}{l}-0.141 \\
(0.477)\end{array}$ & $\begin{array}{l}0.489 \\
(0.510)\end{array}$ & $\begin{array}{c}-0.460 \\
(0.854)\end{array}$ \\
\hline $\mathrm{SCA}$ & $\begin{array}{l}-0.014 \\
(0.059)\end{array}$ & $\begin{array}{l}0.042 \\
(0.081)\end{array}$ & $\begin{array}{l}1.300^{* * *} \\
(0.268)\end{array}$ & $\begin{array}{l}0.047 \\
(0.417)\end{array}$ & $\begin{array}{c}0.955^{* *} \\
(0.390)\end{array}$ & $\begin{array}{l}1.029 \\
(0.636)\end{array}$ \\
\hline Education & $\begin{array}{l}0.025^{* * *} \\
(0.0009)\end{array}$ & & $\begin{array}{l}0.071^{* * *} \\
(0.003)\end{array}$ & & & \\
\hline Observations & 40985 & & 40985 & & & \\
\hline PR2 & 0.034 & & 0.031 & & & \\
\hline 11 & -25598 & & -84619 & & & \\
\hline
\end{tabular}


Table 19: Child suffers from working mother

\begin{tabular}{|c|c|c|c|c|c|c|}
\hline & All & & Pre-1970 & & Post-1970 & \\
\hline Origin & 1 1st & 2nd & 1st & 2nd & $\overline{1 \mathrm{st}}$ & 2nd \\
\hline$\overline{\overline{W E}}$ & $\begin{array}{l}-0.215^{*} \\
(0.113)\end{array}$ & $\begin{array}{l}-0.189 \\
(0.122)\end{array}$ & $\begin{array}{l}-0.302^{* *} \\
(0.121)\end{array}$ & $\begin{array}{l}-0.054 \\
(0.158)\end{array}$ & $\begin{array}{l}0.333 \\
(0.295)\end{array}$ & $\begin{array}{c}-0.367^{*} \\
(0.189)\end{array}$ \\
\hline SE & $\begin{array}{l}0.768^{* * *} \\
(0.142)\end{array}$ & $\begin{array}{l}-0.126 \\
(0.119)\end{array}$ & $\begin{array}{l}0.681^{* * *} \\
(0.159)\end{array}$ & $\begin{array}{l}-0.129 \\
(0.153)\end{array}$ & $\begin{array}{l}1.104^{* * *} \\
(0.315)\end{array}$ & $\begin{array}{l}-0.111 \\
(0.186)\end{array}$ \\
\hline $\mathrm{EE}$ & $\begin{array}{l}0.805^{* * *} \\
(0.223)\end{array}$ & $\begin{array}{l}0.238 \\
(0.394)\end{array}$ & $\begin{array}{l}0.773^{* * *} \\
(0.280)\end{array}$ & $\begin{array}{l}1.195^{* *} \\
(0.544)\end{array}$ & $\begin{array}{l}0.872^{* *} \\
(0.365)\end{array}$ & $\begin{array}{l}-0.796 \\
(0.569)\end{array}$ \\
\hline $\mathrm{AF}$ & $\begin{array}{l}0.981 * \\
(0.559)\end{array}$ & $\begin{array}{l}-1.392 \\
(0.982)\end{array}$ & $\begin{array}{l}1.551^{* *} \\
(0.768)\end{array}$ & $\begin{array}{l}-0.998 \\
(1.329)\end{array}$ & $\begin{array}{l}0.355 \\
(0.816)\end{array}$ & $\begin{array}{l}-1.850 \\
(1.456)\end{array}$ \\
\hline TMM & $\begin{array}{l}2.495^{* * *} \\
(0.492)\end{array}$ & $\begin{array}{l}-0.421 \\
(0.333)\end{array}$ & $\begin{array}{l}2.364^{* * *} \\
(0.627)\end{array}$ & $\begin{array}{l}-0.807 \\
(0.498)\end{array}$ & $\begin{array}{l}2.719 * * * \\
(0.791)\end{array}$ & $\begin{array}{l}-0.101 \\
(0.446)\end{array}$ \\
\hline LA & $\begin{array}{l}1.019 * * * \\
(0.336)\end{array}$ & $\begin{array}{l}0.0389 \\
(0.617)\end{array}$ & $\begin{array}{l}0.324 \\
(0.418)\end{array}$ & $\begin{array}{l}-0.950 \\
(0.871)\end{array}$ & $\begin{array}{l}2.280 * * * \\
(0.560)\end{array}$ & $\begin{array}{l}1.041 \\
(0.872)\end{array}$ \\
\hline AS & $\begin{array}{l}1.686 * * \\
(0.665)\end{array}$ & $\begin{array}{l}1.254 \\
(1.329)\end{array}$ & $\begin{array}{l}1.909^{* * *} \\
(0.729)\end{array}$ & $\begin{array}{l}1.031 \\
(1.879)\end{array}$ & $\begin{array}{l}0.561 \\
(1.627)\end{array}$ & $\begin{array}{l}1.490 \\
(1.879)\end{array}$ \\
\hline SCA & $\begin{array}{l}3.307^{* * *} \\
(0.870)\end{array}$ & $\begin{array}{l}-1.094 \\
(1.152)\end{array}$ & $\begin{array}{l}3.342^{* * *} \\
(1.085)\end{array}$ & $\begin{array}{l}-1.504 \\
(1.628)\end{array}$ & $\begin{array}{l}3.250^{* *} \\
(1.456)\end{array}$ & $\begin{array}{l}-0.670 \\
(1.628)\end{array}$ \\
\hline Education & $\begin{array}{l}-0.229^{* * *} \\
(0.0103)\end{array}$ & & $\begin{array}{l}-0.231^{* * *} \\
(0.0103)\end{array}$ & & & \\
\hline Observations & 15482 & & 15482 & & & \\
\hline $\mathrm{R} 2$ & 0.069 & & 0.071 & & & \\
\hline
\end{tabular}

Table 20: Women penalized in general

\begin{tabular}{lllllll} 
& All & \multicolumn{3}{c}{ Pre-1970 } & Post-1970 \\
\hline \hline Origin & 1st & 2nd & 1st & 2nd & 1st & 2nd \\
\hline \hline WE & $0.405^{* * *}$ & $0.258^{* * *}$ & $0.454^{* * *}$ & 0.121 & $-0.314^{*}$ & 0.006 \\
& $(0.091)$ & $(0.097)$ & $(0.075)$ & $(0.108)$ & $(0.179)$ & $(0.127)$ \\
SE & 0.162 & -0.017 & -0.121 & $0.393^{* * *}$ & 0.037 & $0.284^{* *}$ \\
& $(0.101)$ & $(0.092)$ & $(0.099)$ & $(0.103)$ & $(0.209)$ & $(0.119)$ \\
$\mathrm{EE}$ & $-1.145^{* * *}$ & -0.346 & $-0.581^{* * *}$ & 0.564 & $-0.682^{* * *}$ & -0.008 \\
& $(0.190)$ & $(0.261)$ & $(0.185)$ & $(0.395)$ & $(0.239)$ & $(0.386)$ \\
$\mathrm{AF}$ & $-0.982^{* *}$ & 0.565 & $0.989^{*}$ & -1.196 & 0.191 & 1.370 \\
& $(0.434)$ & $(0.761)$ & $(0.505)$ & $(1.029)$ & $(0.565)$ & $(1.030)$ \\
TMM & $-0.996^{* * *}$ & -0.183 & 0.423 & -0.034 & -0.026 & -0.513 \\
& $(0.249)$ & $(0.370)$ & $(0.415)$ & $(0.344)$ & $(0.505)$ & $(0.315)$ \\
LA & 0.192 & $0.869^{*}$ & 0.148 & -0.456 & -0.176 & 0.981 \\
& $(0.359)$ & $(0.459)$ & $(0.246)$ & $(0.674)$ & $(0.305)$ & $(0.613)$ \\
AS & -0.818 & -0.562 & -0.693 & 1.479 & 1.113 & $2.900^{* *}$ \\
& $(0.590)$ & $(1.076)$ & $(0.461)$ & $(1.456)$ & $(1.128)$ & $(1.456)$ \\
SCA & $-1.282^{* * *}$ & $-1.402^{*}$ & -0.372 & 0.795 & -0.015 & -0.015 \\
& $(0.356)$ & $(0.795)$ & $(0.841)$ & $(1.261)$ & $(0.892)$ & $(1.261)$ \\
Education & $0.072^{* * *}$ & & $0.101^{* * *}$ & & & \\
& $(0.007)$ & & $(0.006)$ & & & \\
\hline Observations & 19449 & & 19449 & & \\
R2 & 0.064 & 0.064 & & \\
\hline \hline Source: SHP, $1999-2007 ;$ Standard errors in parentheses; *** p<0.01,** $\mathrm{p}<0.05, * \mathrm{p}<0.1$.
\end{tabular}


Table 21: Probability to participate to religious offices more than for special occasions

\begin{tabular}{lllllll} 
& All & \multicolumn{3}{c}{ Pre-1970 } & Post-1970 \\
\hline \hline Origin & 1st & 2nd & 1st & 2nd & 1st & 2nd \\
\hline \hline WE & $-0.110^{* * *}$ & $-0.031^{* * *}$ & $-0.086^{* * *}$ & -0.012 & $-0.194^{* * *}$ & $-0.073^{* * *}$ \\
& $(0.009)$ & $(0.011)$ & $(0.010)$ & $(0.014)$ & $(0.019)$ & $(0.016)$ \\
SE & $0.042^{* * *}$ & $0.023^{*}$ & $0.060^{* * *}$ & $0.040^{* * *}$ & -0.014 & -0.006 \\
& $(0.013)$ & $(0.012)$ & $(0.013)$ & $(0.015)$ & $(0.030)$ & $(0.017)$ \\
EE & $0.079^{* * *}$ & -0.033 & 0.036 & -0.032 & $0.123^{* * *}$ & -0.051 \\
& $(0.024)$ & $(0.033)$ & $(0.028)$ & $(0.045)$ & $(0.037)$ & $(0.044)$ \\
AF & $0.176^{* * *}$ & 0.006 & $0.224^{* * *}$ & -0.059 & 0.064 & 0.239 \\
& $(0.054)$ & $(0.096)$ & $(0.063)$ & $(0.111)$ & $(0.079)$ & $(0.151)$ \\
TMM & 0.033 & $-0.145^{* * *}$ & $0.102^{* *}$ & $-0.116^{* * *}$ & $-0.146^{* * *}$ & $-0.139^{* * *}$ \\
& $(0.039)$ & $(0.029)$ & $(0.045)$ & $(0.044)$ & $(0.049)$ & $(0.038)$ \\
LA & $0.112^{* * *}$ & 0.0135 & $0.158^{* * *}$ & 0.079 & $0.101^{*}$ & $-0.196^{* * *}$ \\
& $(0.038)$ & $(0.063)$ & $(0.044)$ & $(0.078)$ & $(0.060)$ & $(0.073)$ \\
AS & 0.084 & -0.023 & $0.138^{*}$ & 0.068 & 0.002 & \\
& $(0.071)$ & $(0.108)$ & $(0.080)$ & $(0.136)$ & $(0.110)$ & \\
SCA & $0.261^{* * *}$ & 0.044 & $0.328^{* * *}$ & 0.041 & $0.171^{*}$ & 0.018 \\
& $(0.057)$ & $(0.092)$ & $(0.062)$ & $(0.106)$ & $(0.092)$ & $(0.180)$ \\
Education & $-0.012^{* * *}$ & & $-0.014^{* * *}$ & & & \\
& $(0.0009)$ & & $(0.0009)$ & & & \\
\hline Observations & 32887 & & 32887 & & & \\
PR2 & 0.034 & & 0.033 & & & \\
ll & -19718 & & -22640 & & & \\
\hline \hline
\end{tabular}

Source: SHP, 1999-2007; Standard errors in parentheses; ${ }^{* *} \mathrm{p}<0.01,{ }^{* *} \mathrm{p}<0.05,{ }^{*} \mathrm{p}<0.1$.

Table 22: Probability to pray at least occasionally

\begin{tabular}{|c|c|c|c|c|c|c|}
\hline & All & & Pre-1970 & & Post-1970 & \\
\hline Origin & 1st & 2nd & 1st & 2nd & 1st & 2nd \\
\hline WE & $\begin{array}{l}-0.123^{* * *} \\
(0.010)\end{array}$ & $\begin{array}{l}-0.041 * * * \\
(0.010)\end{array}$ & $\begin{array}{l}-0.088^{* * *} \\
(0.010)\end{array}$ & $\begin{array}{c}-0.031^{* *} \\
(0.013)\end{array}$ & $\begin{array}{l}-0.197 * * * \\
(0.024)\end{array}$ & $\begin{array}{l}-0.064^{* * *} \\
(0.015)\end{array}$ \\
\hline SE & $\begin{array}{l}0.060^{* * *} \\
(0.010)\end{array}$ & $\begin{array}{l}0.050^{* * *} \\
(0.009)\end{array}$ & $\begin{array}{l}0.044^{* * *} \\
(0.011)\end{array}$ & $\begin{array}{l}0.037^{* * * *} \\
(0.012)\end{array}$ & $\begin{array}{l}0.084^{* * *} \\
(0.022)\end{array}$ & $\begin{array}{l}0.060^{* * * *} \\
(0.013)\end{array}$ \\
\hline $\mathrm{EE}$ & $\begin{array}{l}0.021 \\
(0.019)\end{array}$ & $\begin{array}{l}-0.068^{* *} \\
(0.031)\end{array}$ & $\begin{array}{l}0.012 \\
(0.022)\end{array}$ & $\begin{array}{l}-0.035 \\
(0.044)\end{array}$ & $\begin{array}{l}0.063^{* *} \\
(0.026)\end{array}$ & $\begin{array}{l}-0.103^{* *} \\
(0.043)\end{array}$ \\
\hline $\mathrm{AF}$ & $\begin{array}{l}0.138^{* * *} \\
(0.036)\end{array}$ & $\begin{array}{l}-0.153 \\
(0.097)\end{array}$ & $\begin{array}{l}0.182^{* * *} \\
(0.038)\end{array}$ & $\begin{array}{l}-0.244^{* *} \\
(0.118)\end{array}$ & $\begin{array}{l}0.084 \\
(0.058)\end{array}$ & $\begin{array}{l}0.011 \\
(0.137)\end{array}$ \\
\hline TMM & $\begin{array}{l}-0.052 \\
(0.035)\end{array}$ & $\begin{array}{l}-0.052 \\
(0.034)\end{array}$ & $\begin{array}{c}-0.072^{*} \\
(0.042)\end{array}$ & $\begin{array}{l}-0.010 \\
(0.048)\end{array}$ & $\begin{array}{l}-0.067 \\
(0.056)\end{array}$ & $\begin{array}{l}-0.029 \\
(0.042)\end{array}$ \\
\hline LA & $\begin{array}{l}0.098 * * * \\
(0.028)\end{array}$ & $\begin{array}{l}0.112^{* * *} \\
(0.042)\end{array}$ & $\begin{array}{l}0.143^{* * *} \\
(0.029)\end{array}$ & $\begin{array}{l}0.140^{* * *} \\
(0.053)\end{array}$ & $\begin{array}{l}0.123^{* * *} \\
(0.040)\end{array}$ & $\begin{array}{l}0.065 \\
(0.070)\end{array}$ \\
\hline AS & $\begin{array}{l}0.011 \\
(0.059)\end{array}$ & $\begin{array}{l}-0.070 \\
(0.105)\end{array}$ & $\begin{array}{l}-0.018 \\
(0.072)\end{array}$ & $\begin{array}{l}0.028 \\
(0.113)\end{array}$ & $\begin{array}{l}0.106 \\
(0.071)\end{array}$ & $\begin{array}{l}-0.216 \\
(0.179)\end{array}$ \\
\hline $\mathrm{SCA}$ & $\begin{array}{l}0.131^{* * *} \\
(0.038)\end{array}$ & $\begin{array}{l}0.100 \\
(0.068)\end{array}$ & $\begin{array}{l}0.161^{* * *} \\
(0.041)\end{array}$ & $\begin{array}{l}0.040 \\
(0.098)\end{array}$ & $\begin{array}{l}0.069 \\
(0.071)\end{array}$ & $\begin{array}{l}0.170^{*} \\
(0.090)\end{array}$ \\
\hline Education & $\begin{array}{l}-0.006^{* * *} \\
(0.0008)\end{array}$ & & $\begin{array}{l}-0.011^{* * *} \\
(0.0007)\end{array}$ & & & \\
\hline Observations & 41601 & & 41601 & & & \\
\hline PR2 & 0.047 & & 0.029 & & & \\
\hline 11 & -24118 & & -28654 & & & \\
\hline
\end{tabular}


Table 23: Political affiliation

\begin{tabular}{|c|c|c|c|c|c|c|}
\hline & \multicolumn{2}{|l|}{ All } & \multicolumn{2}{|l|}{ Pre-1970 } & \multicolumn{2}{|l|}{ Post-1970 } \\
\hline Origin & 1st & 2nd & 1st & 2nd & 1st & 2nd \\
\hline$\overline{\mathrm{WE}}$ & $\begin{array}{l}-0.541^{* * *} \\
(0.073)\end{array}$ & $\begin{array}{l}-0.215^{* * *} \\
(0.078)\end{array}$ & $\begin{array}{l}-0.244^{* * *} \\
(0.048)\end{array}$ & $\begin{array}{l}-0.199^{* * *} \\
(0.063)\end{array}$ & $\begin{array}{l}-0.408^{* * *} \\
(0.107)\end{array}$ & $\begin{array}{l}-0.261^{* * *} \\
(0.079)\end{array}$ \\
\hline SE & $\begin{array}{l}-2.080^{* * *} \\
(0.086)\end{array}$ & $\begin{array}{l}-0.826^{* * *} \\
(0.078)\end{array}$ & $\begin{array}{l}-0.699^{* * *} \\
(0.065)\end{array}$ & $\begin{array}{l}-0.311^{* * *} \\
(0.064)\end{array}$ & $\begin{array}{l}-0.236 \\
(0.149)\end{array}$ & $\begin{array}{l}-0.696^{* * *} \\
(0.076)\end{array}$ \\
\hline $\mathrm{EE}$ & $\begin{array}{l}-1.875^{* * *} \\
(0.153)\end{array}$ & $\begin{array}{l}-0.281 \\
(0.226)\end{array}$ & $\begin{array}{l}-0.040 \\
(0.129)\end{array}$ & $\begin{array}{l}0.246 \\
(0.204)\end{array}$ & $\begin{array}{l}-0.859^{* * *} \\
(0.174)\end{array}$ & $\begin{array}{l}-0.766^{* * *} \\
(0.207)\end{array}$ \\
\hline $\mathrm{AF}$ & $\begin{array}{l}-2.546^{* * *} \\
(0.366)\end{array}$ & $\begin{array}{l}0.622 \\
(0.641)\end{array}$ & $\begin{array}{l}-1.400^{* * *} \\
(0.310)\end{array}$ & $\begin{array}{l}0.003 \\
(0.496)\end{array}$ & $\begin{array}{l}-1.421^{* * *} \\
(0.448)\end{array}$ & $\begin{array}{l}-0.067 \\
(0.665)\end{array}$ \\
\hline TMM & $\begin{array}{l}-1.193^{* * *} \\
(0.266)\end{array}$ & $\begin{array}{l}-0.584^{* *} \\
(0.248)\end{array}$ & $\begin{array}{l}-0.023 \\
(0.206)\end{array}$ & $\begin{array}{l}-0.098 \\
(0.228)\end{array}$ & $\begin{array}{l}-1.091^{* * *} \\
(0.263)\end{array}$ & $\begin{array}{l}-0.841^{* * *} \\
(0.229)\end{array}$ \\
\hline LA & $\begin{array}{l}-1.716^{* * *} \\
(0.250)\end{array}$ & $\begin{array}{l}-0.830^{* *} \\
(0.400)\end{array}$ & $\begin{array}{l}-0.868^{* * *} \\
(0.187)\end{array}$ & $\begin{array}{l}-0.450 \\
(0.307)\end{array}$ & $\begin{array}{l}-0.411 \\
(0.257)\end{array}$ & $\begin{array}{l}-1.206^{* * *} \\
(0.421)\end{array}$ \\
\hline AS & $\begin{array}{l}-1.212^{* *} \\
(0.484)\end{array}$ & $\begin{array}{l}0.396 \\
(0.740)\end{array}$ & $\begin{array}{l}-0.290 \\
(0.355)\end{array}$ & $\begin{array}{l}0.0140 \\
(0.543)\end{array}$ & $\begin{array}{l}-1.118^{* *} \\
(0.510)\end{array}$ & $\begin{array}{l}-0.600 \\
(0.940)\end{array}$ \\
\hline SCA & $\begin{array}{l}-2.182^{* * *} \\
(0.392)\end{array}$ & $\begin{array}{l}-0.298 \\
(0.619)\end{array}$ & $\begin{array}{l}-0.394 \\
(0.355)\end{array}$ & $\begin{array}{l}-0.068 \\
(0.482)\end{array}$ & $\begin{array}{l}0.257 \\
(0.448)\end{array}$ & $\begin{array}{l}-1.721^{* *} \\
(0.701)\end{array}$ \\
\hline Education & $\begin{array}{l}0.092^{* * *} \\
(0.006)\end{array}$ & & $\begin{array}{l}-0.054^{* * *} \\
(0.003)\end{array}$ & & & \\
\hline Observations & 40985 & & 40985 & & & \\
\hline $\mathrm{R} 2$ & 0.053 & & 0.036 & & & \\
\hline
\end{tabular}

Table 24: Satisfaction with Swiss democracy

\begin{tabular}{|c|c|c|c|c|c|c|}
\hline & \multicolumn{2}{|l|}{ All } & \multicolumn{2}{|l|}{ Pre-1970 } & \multicolumn{2}{|l|}{ Post-1970 } \\
\hline Origin & $1 \mathrm{st}$ & 2nd & 1 st & 2nd & 1 st & 2nd \\
\hline$\overline{\mathrm{WE}}$ & $\begin{array}{l}0.168^{* * *} \\
(0.041)\end{array}$ & $\begin{array}{l}-0.017 \\
(0.044)\end{array}$ & $\begin{array}{l}0.266^{* * *} \\
(0.045)\end{array}$ & $\begin{array}{l}0.032 \\
(0.056)\end{array}$ & $\begin{array}{l}-0.350^{* * *} \\
(0.103)\end{array}$ & $\begin{array}{c}-0.125^{*} \\
(0.071)\end{array}$ \\
\hline $\mathrm{SE}$ & $\begin{array}{l}-0.053 \\
(0.048)\end{array}$ & $\begin{array}{l}-0.102^{* *} \\
(0.044)\end{array}$ & $\begin{array}{l}0.073 \\
(0.053)\end{array}$ & $\begin{array}{l}-0.043 \\
(0.056)\end{array}$ & $\begin{array}{l}-0.665^{* * *} \\
(0.117)\end{array}$ & $\begin{array}{l}-0.214^{* * *} \\
(0.069)\end{array}$ \\
\hline $\mathrm{EE}$ & $\begin{array}{l}0.975^{* * *} \\
(0.086)\end{array}$ & $\begin{array}{l}0.293^{* *} \\
(0.127)\end{array}$ & $\begin{array}{l}0.964^{* * *} \\
(0.107)\end{array}$ & $\begin{array}{l}0.095 \\
(0.177)\end{array}$ & $\begin{array}{l}0.975^{* * *} \\
(0.144)\end{array}$ & $\begin{array}{l}0.473^{* * *} \\
(0.183)\end{array}$ \\
\hline $\mathrm{AF}$ & $\begin{array}{l}0.744^{* * *} \\
(0.206)\end{array}$ & $\begin{array}{l}0.598^{*} \\
(0.361)\end{array}$ & $\begin{array}{l}0.953^{* * *} \\
(0.258)\end{array}$ & $\begin{array}{l}0.246 \\
(0.438)\end{array}$ & $\begin{array}{l}0.343 \\
(0.343)\end{array}$ & $\begin{array}{l}1.330^{* *} \\
(0.636)\end{array}$ \\
\hline TMM & $\begin{array}{l}0.950^{* * * *} \\
(0.150)\end{array}$ & $\begin{array}{l}0.257^{*} \\
(0.140)\end{array}$ & $\begin{array}{l}1.188^{* * *} \\
(0.188)\end{array}$ & $\begin{array}{l}-0.057 \\
(0.201)\end{array}$ & $\begin{array}{l}0.516^{* *} \\
(0.249)\end{array}$ & $\begin{array}{l}0.519 * * * \\
(0.195)\end{array}$ \\
\hline LA & $\begin{array}{l}0.038 \\
(0.141)\end{array}$ & $\begin{array}{l}0.390^{*} \\
(0.226)\end{array}$ & $\begin{array}{l}0.309^{*} \\
(0.171)\end{array}$ & $\begin{array}{l}0.549^{* *} \\
(0.276)\end{array}$ & $\begin{array}{l}-0.559^{* *} \\
(0.249)\end{array}$ & $\begin{array}{l}0.041 \\
(0.390)\end{array}$ \\
\hline AS & $\begin{array}{l}0.608^{* *} \\
(0.273)\end{array}$ & $\begin{array}{l}-0.212 \\
(0.417)\end{array}$ & $\begin{array}{l}0.656^{* *} \\
(0.323)\end{array}$ & $\begin{array}{l}-0.141 \\
(0.477)\end{array}$ & $\begin{array}{l}0.489 \\
(0.510)\end{array}$ & $\begin{array}{l}-0.460 \\
(0.854)\end{array}$ \\
\hline SCA & $\begin{array}{l}1.192^{* * *} \\
(0.221)\end{array}$ & $\begin{array}{l}0.348 \\
(0.349)\end{array}$ & $\begin{array}{l}1.300^{* * *} \\
(0.268)\end{array}$ & $\begin{array}{l}0.047 \\
(0.417)\end{array}$ & $\begin{array}{l}0.955^{* *} \\
(0.390)\end{array}$ & $\begin{array}{l}1.029 \\
(0.636)\end{array}$ \\
\hline Education & $\begin{array}{l}0.069^{* * *} \\
(0.003)\end{array}$ & & $\begin{array}{l}0.071^{* * *} \\
(0.003)\end{array}$ & & & \\
\hline Observations & 40985 & & 40985 & & & \\
\hline $\mathrm{R} 2$ & 0.029 & & 0.031 & & & \\
\hline
\end{tabular}



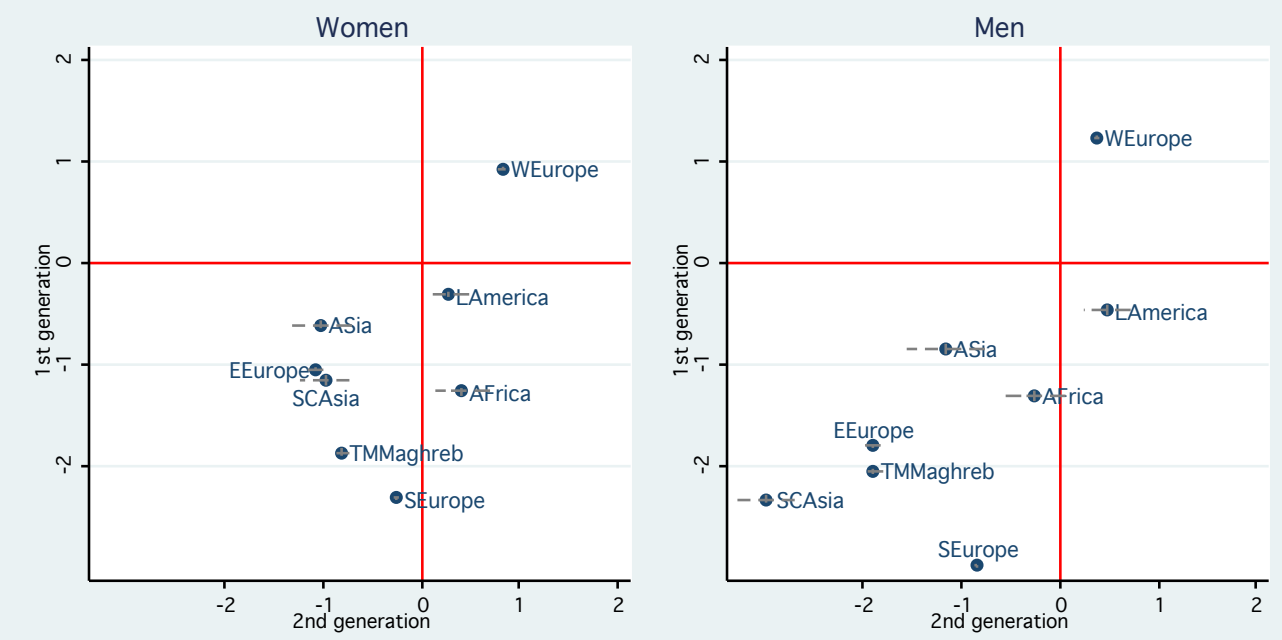

Data: Swiss census, 2000; sample: all aged 25+

Educational attainment $=$ number of years of education

Figure 2: Educational attainment 

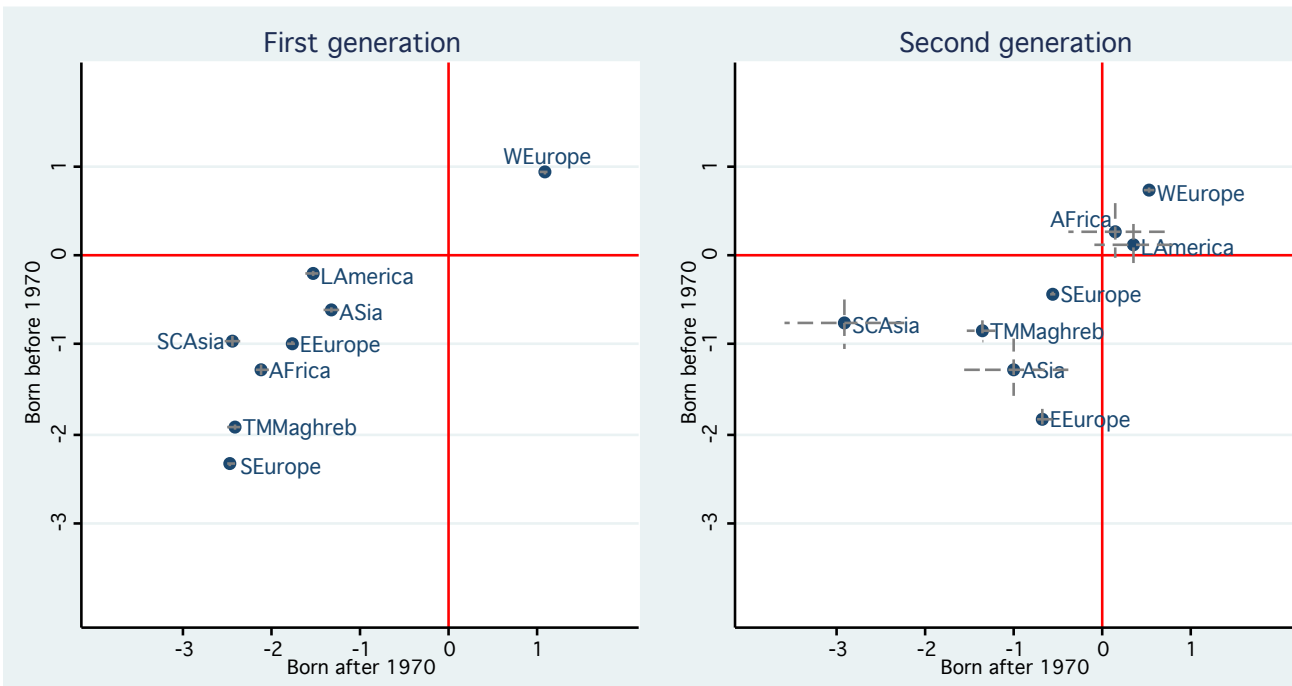

Data: Swiss census, 2000; sample: all women aged $25+$ Educational attainment $=$ number of years of education

Figure 3: Female educational attainment
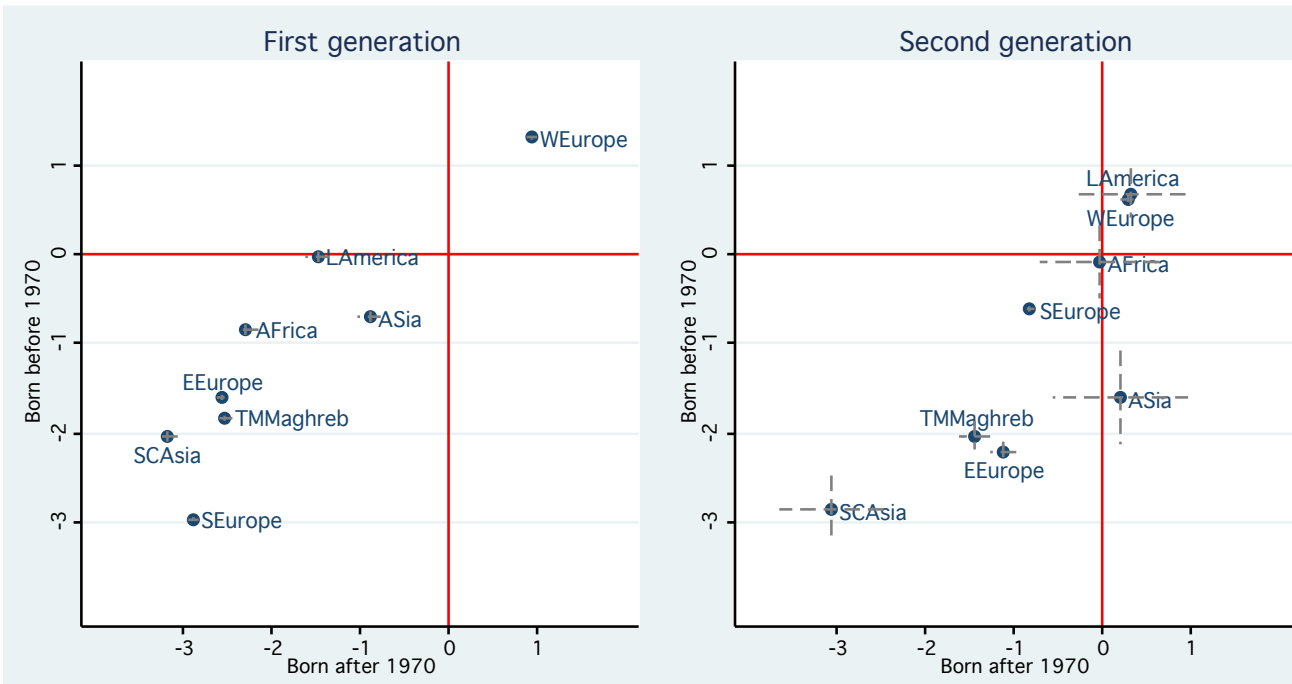

Data: Swiss census, 2000; sample: all men aged 25+

Educational attainment $=$ number of years of education

Figure 4: Male educational attainment 


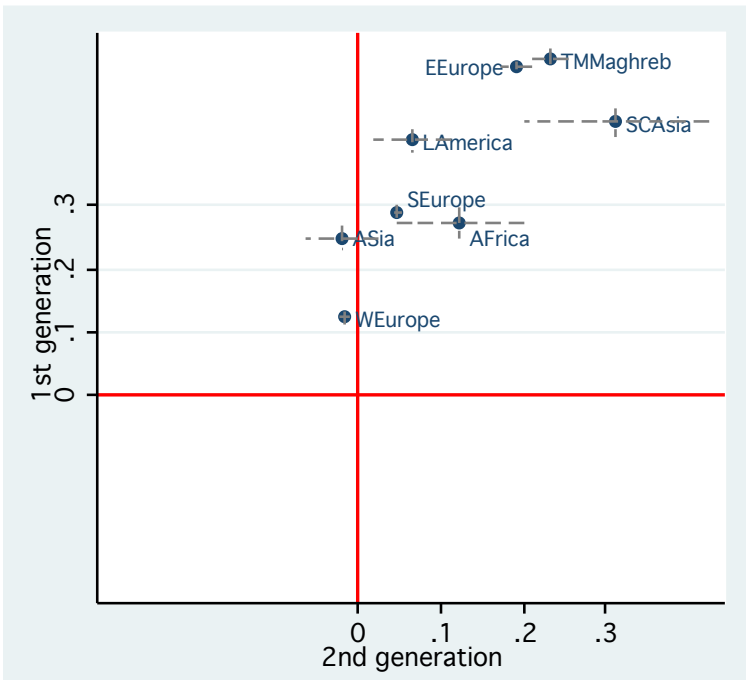

Data: Swiss census, 2000; sample: all women age 18 to 25 and not widow Married $=$ dummy 1 if married, 0 if not

Figure 5: Marriage
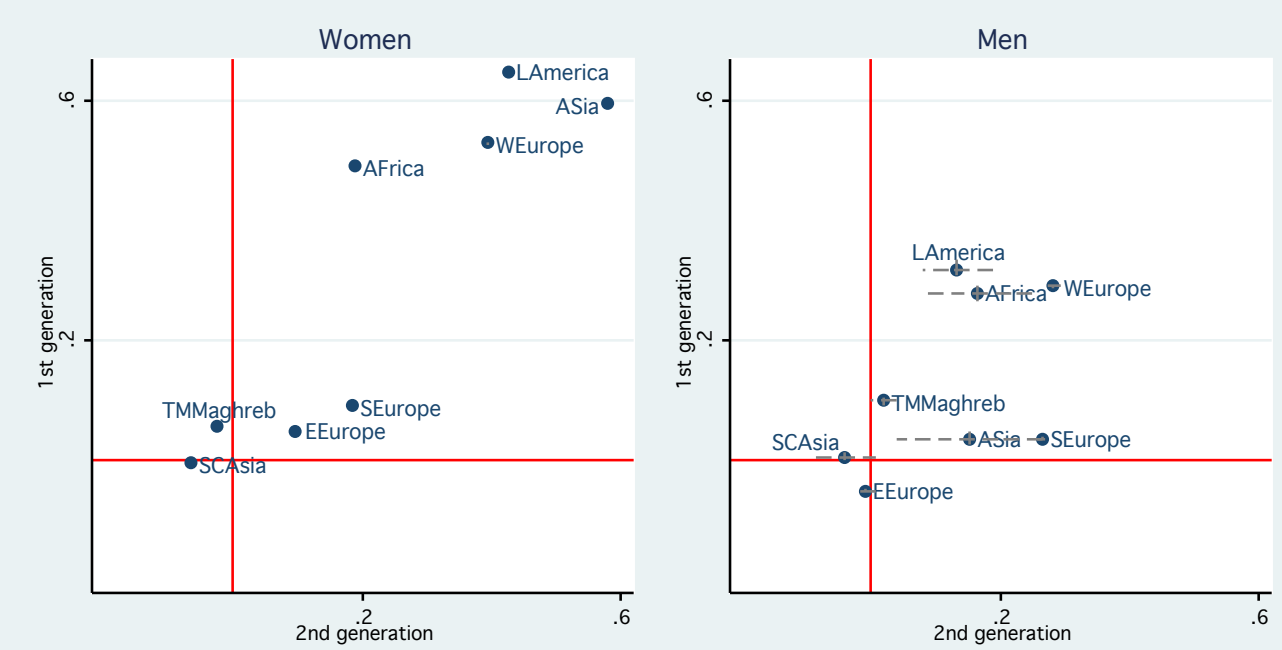

Data: Swiss census, 2000; sample: all in couple

Mixed = dummy 1 if mixed, 0 if endogamous couple

Figure 6: Mixed couple 


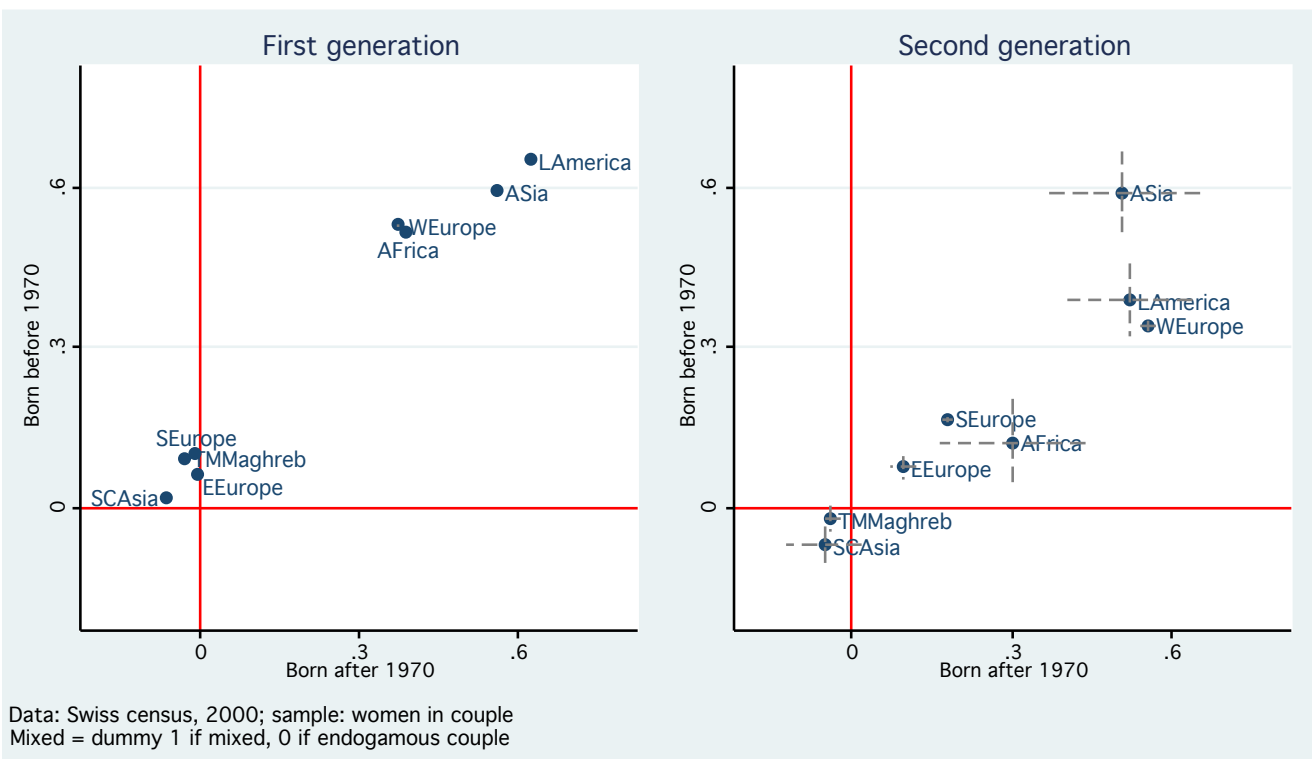

Figure 7: Women in mixed couples

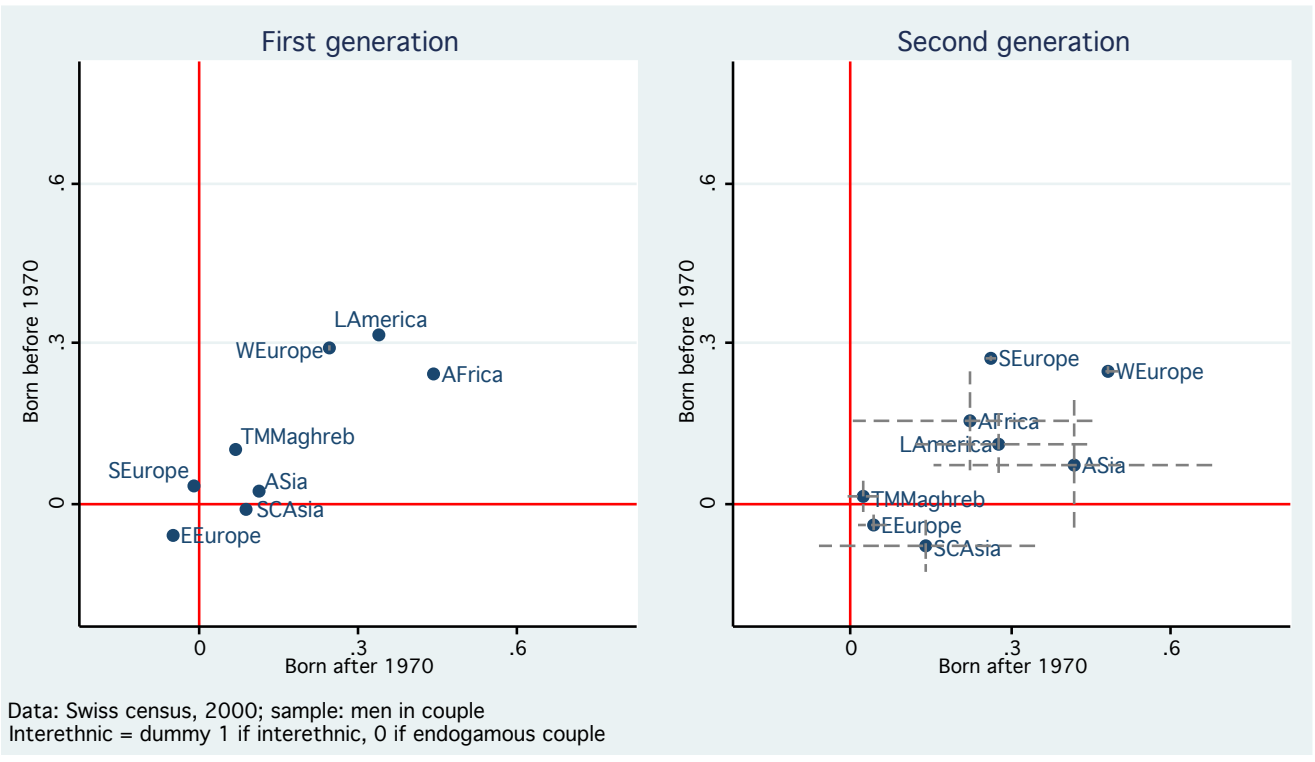

Figure 8: Men in mixed couples 

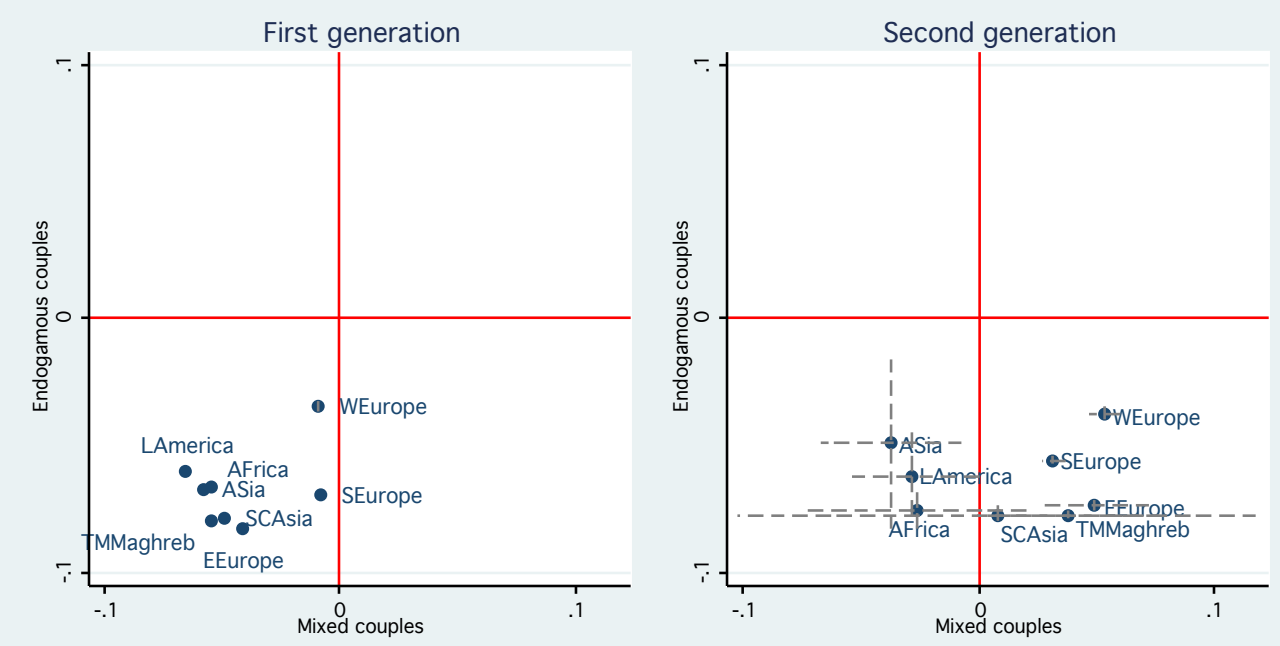

Data: Swiss census, 2000; sample: all women age 18+ with partner Cohabitation = dummy 1 if cohabiting, 0 if married

Figure 9: Cohabitation
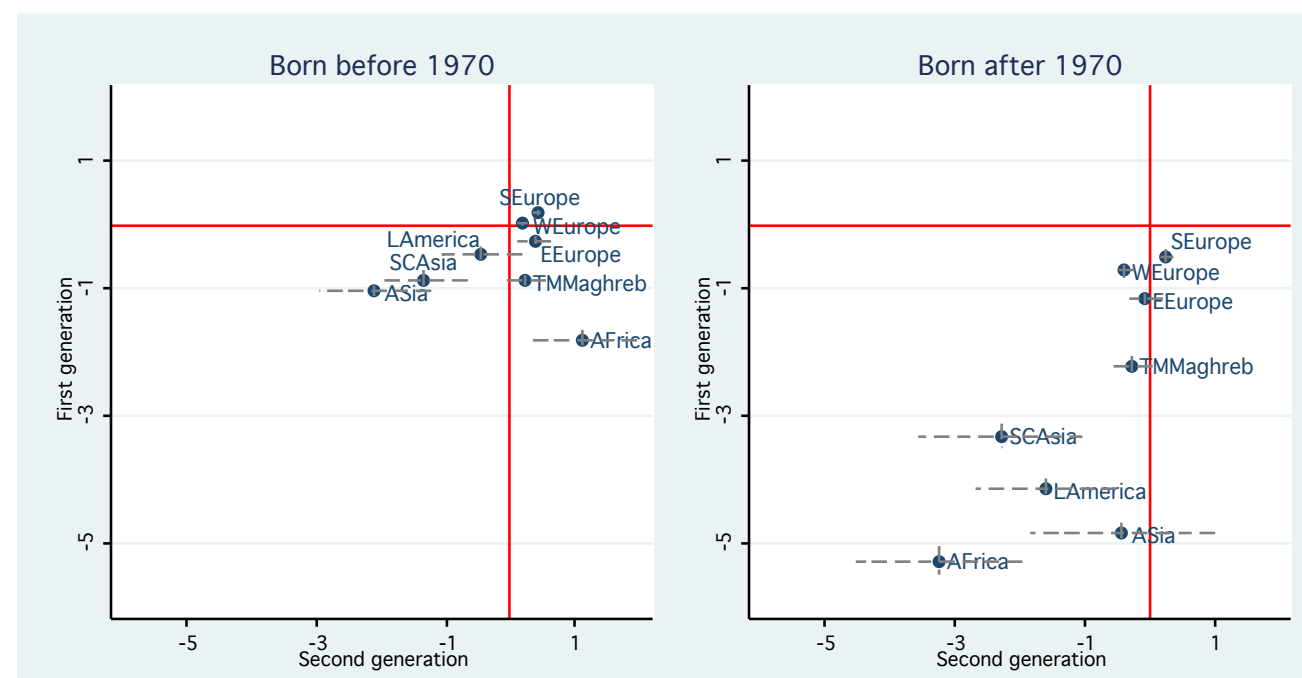

Data: Swiss census, 2000; sample: all women

Age gap $=($ age of person/woman - age of partner/man $)$

Figure 10: Age gap between partners 

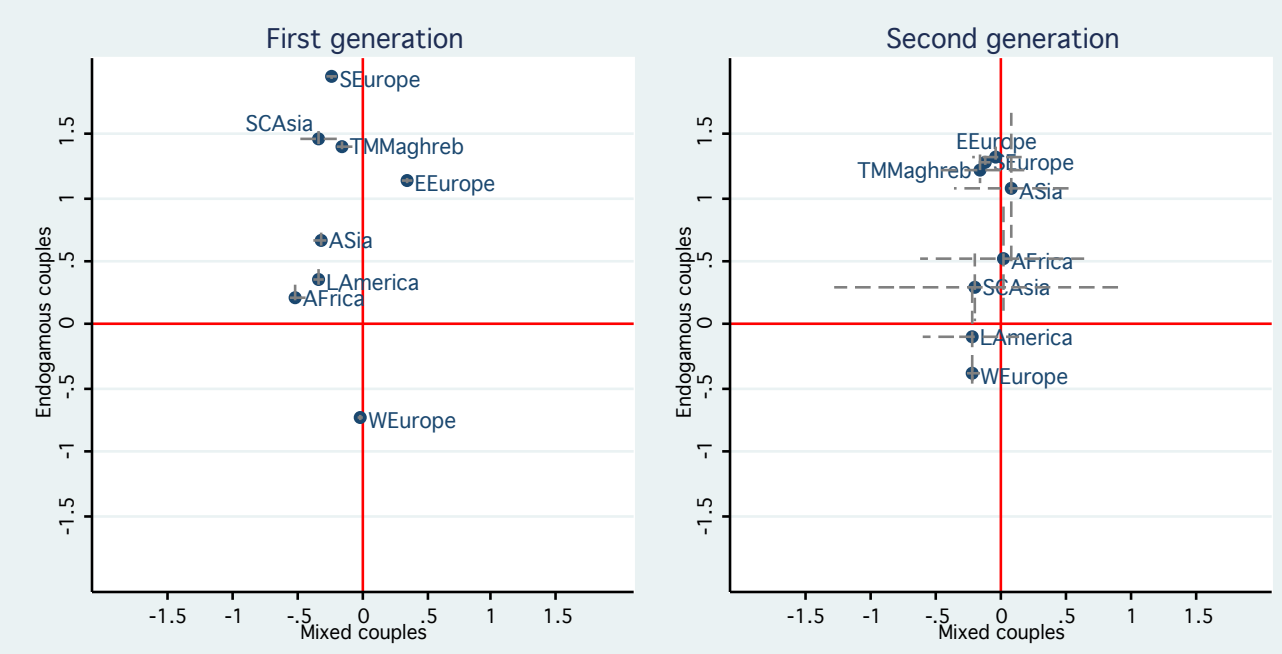

Data: Swiss census, 2000; sample: all women

Education gap $=$ (education of person/woman - education of partner/man $)$

Figure 11: Education gap between partners
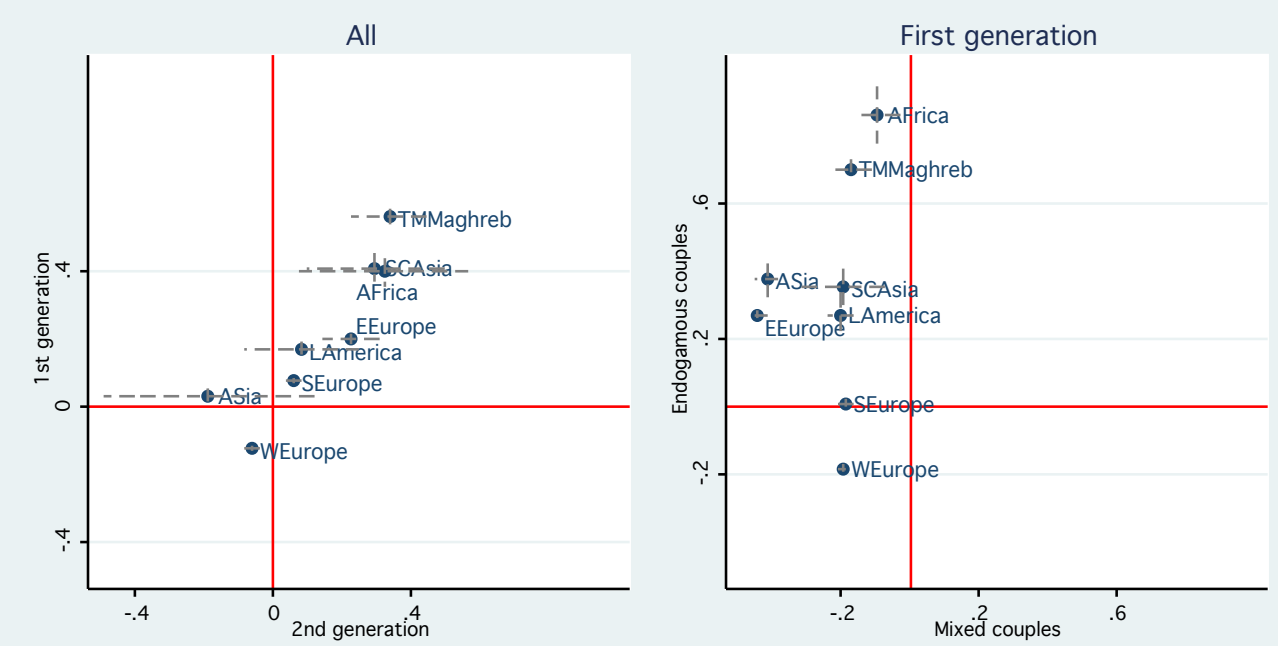

Data: Swiss census, 2000; sample: all women age 40+ Fertility rate $=$ number of children

Figure 12: Completed fertility rate 

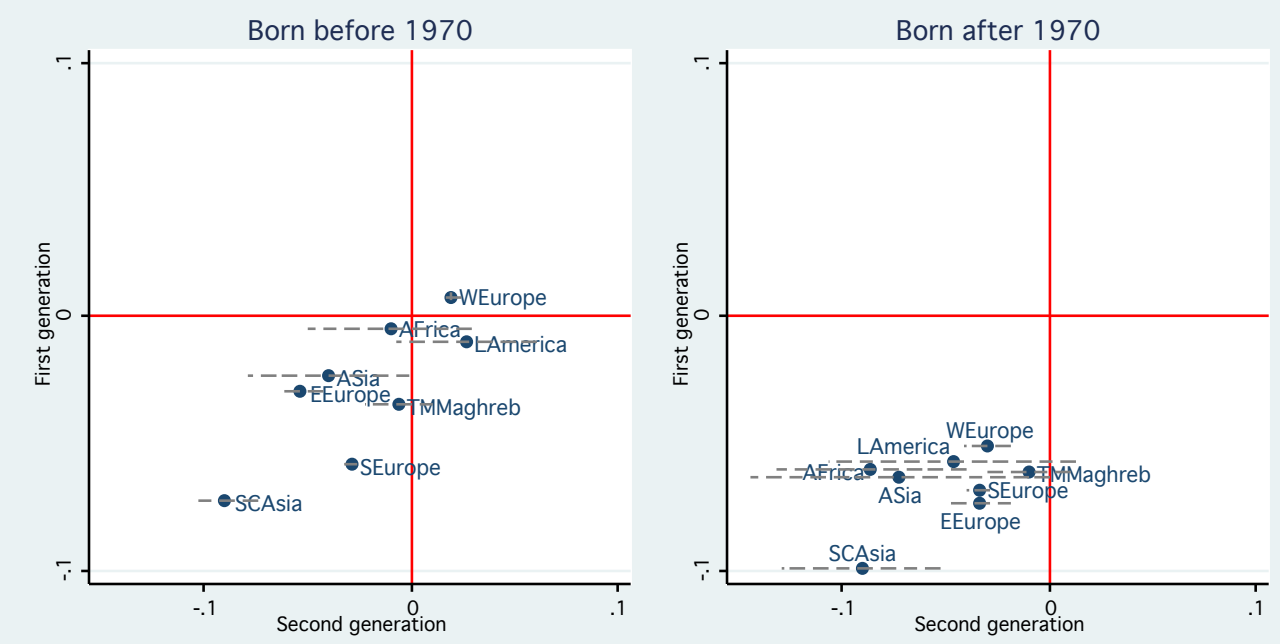

Data: Swiss census, 2000; sample: married and divorced women age 18+ Divorced $=$ dummy 1 if divorced, 0 if not

Figure 13: Divorce

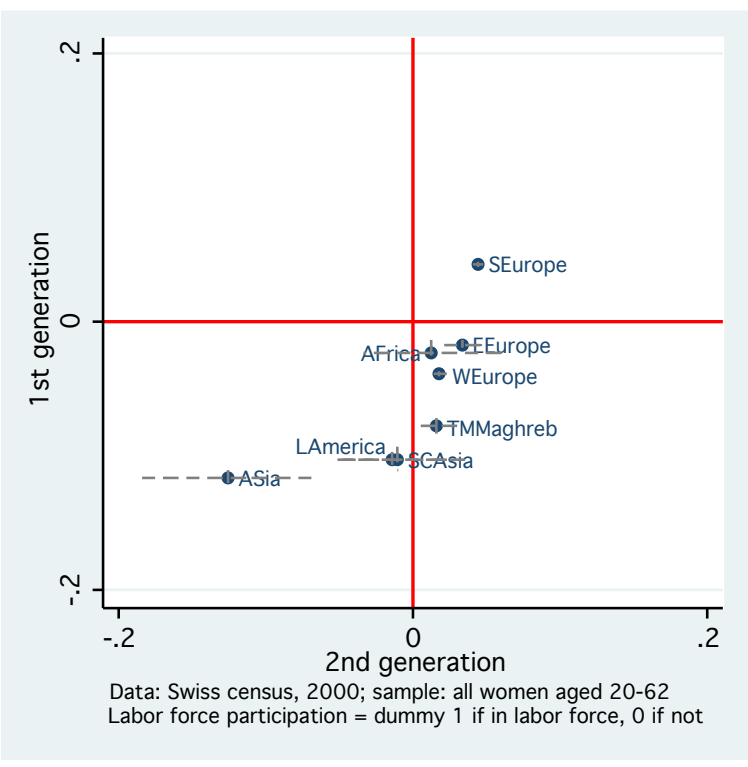

Figure 14: Female labour force participation 

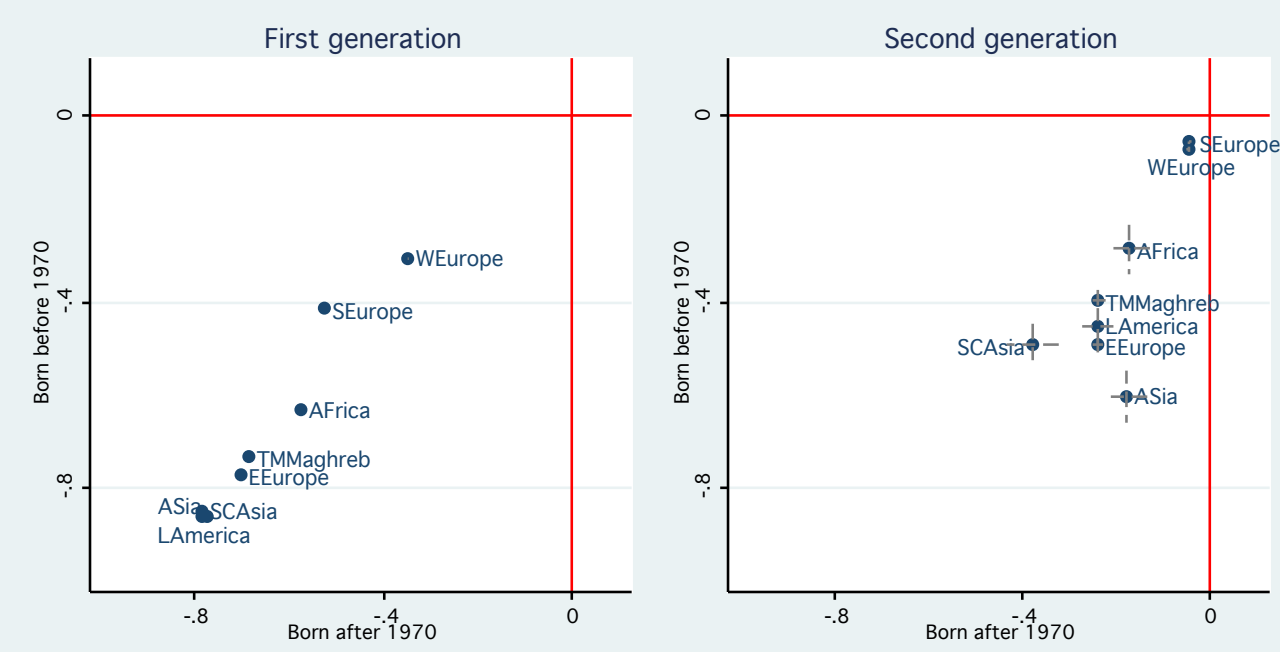

Data: Swiss census, 2000; sample: all age 18+ National language $=1$ if one of four national languages, 0 if not

Figure 15: Main language
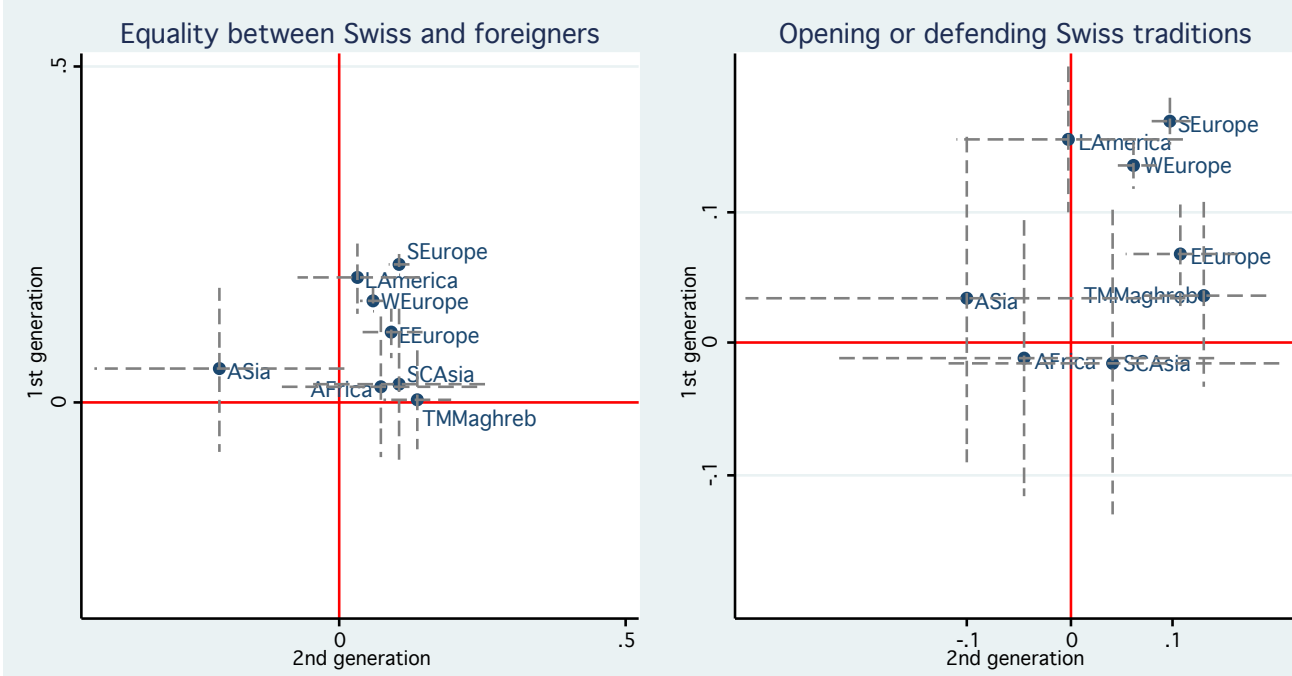

Data: Swiss census, 2000; sample: all women/men

Dummies $=1$ if in favor of equality between Swiss and foreigners/in favor of opening swiss traditions, 0 if not

Figure 16: Feelings towards Switzerland 

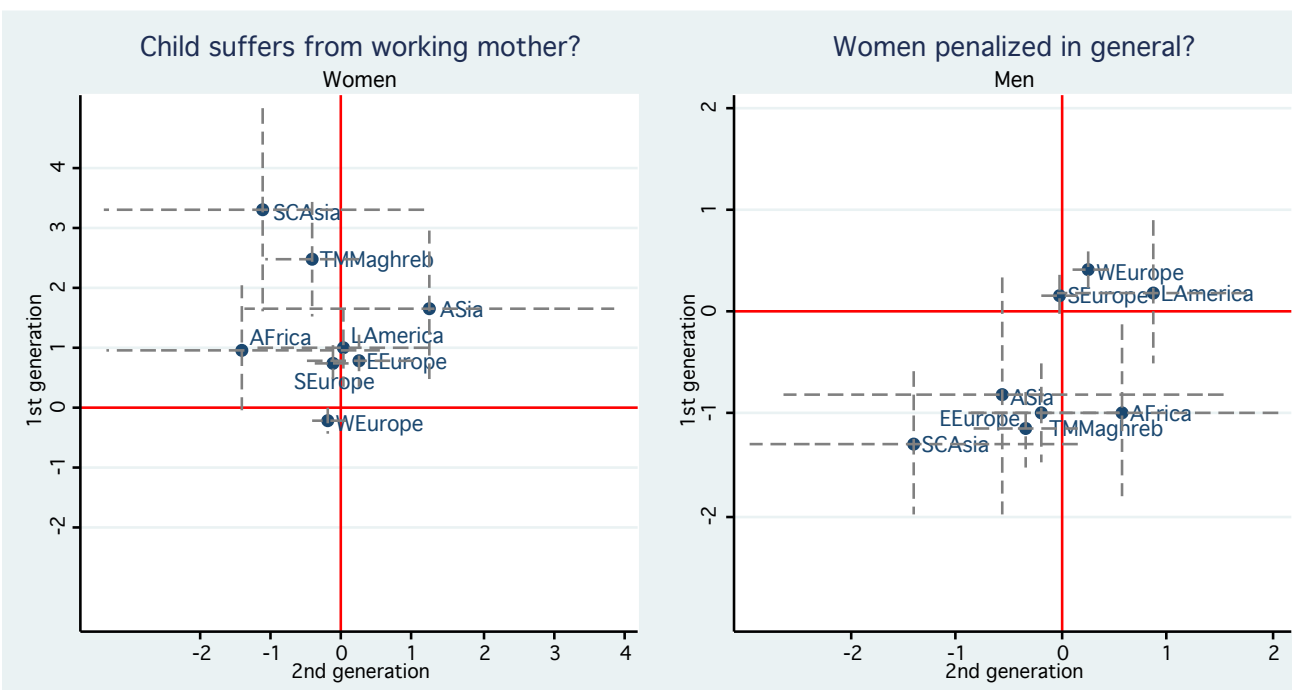

Data: Swiss census, 2000; sample: all women/men

Both variables $=0$ (does not agree at all) to 10 scales

Figure 17: Gender attitudes
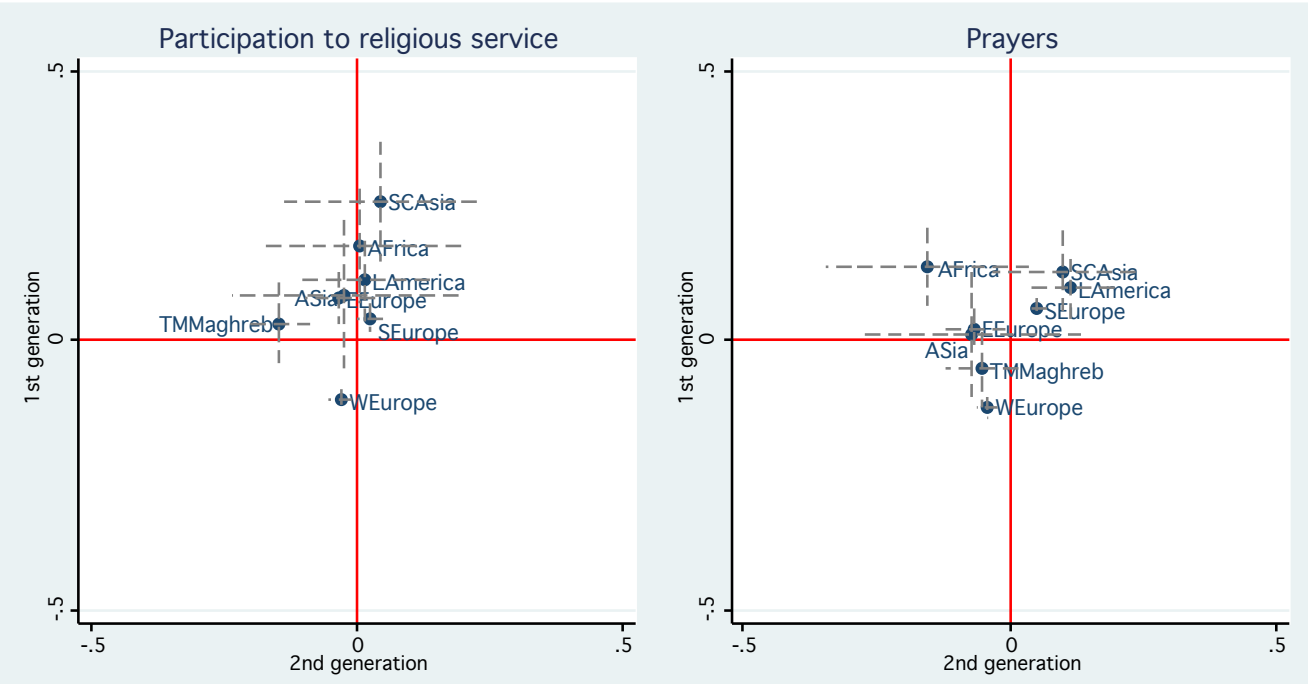

Data: Swiss census, 2000; sample: all women/men

Dummies $=1$ if goes to religious offices not only on special occasions/prays at least occasionally, 0 if not

Figure 18: Religious attitudes 

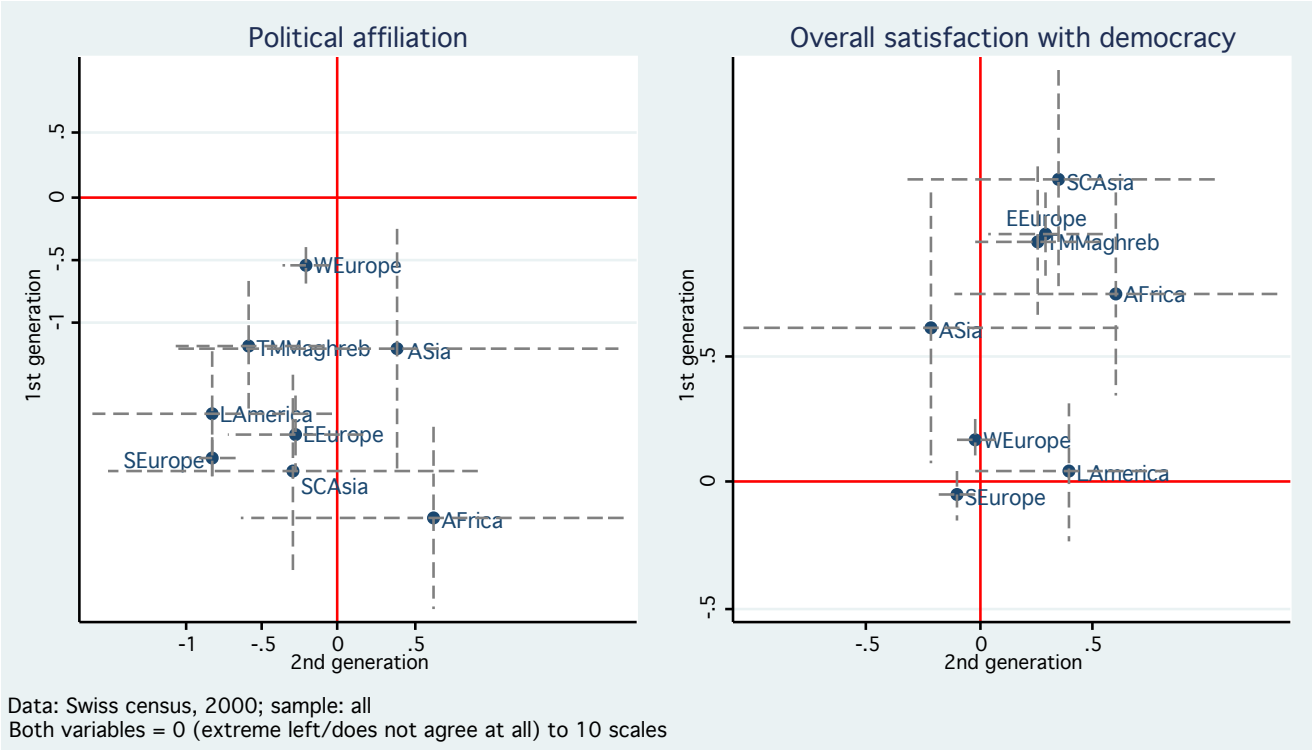

Figure 19: Political attitudes 